Article

\title{
Simulation of Climate Change Impact on A Coastal Aquifer under Arid Climate. The Tadjourah Aquifer (Republic of Djibouti, Horn of Africa)
}

\author{
Moumtaz Razack $1, * \mathbb{D}$, Mohamed Jalludin ${ }^{2}$ and Abdourahman Houmed-Gaba ${ }^{2}$ \\ 1 University of Poitiers, UMR CNRS 7285, 5 rue Albert Turpain, 86073 Poitiers CEDEX 9, France \\ 2 CERD (Center of Studies and Research of Djibouti), PoB 486, Djibouti 999057, Republic of Djibouti; \\ mohamed.jalludin@gmail.com (M.J.); abdogaba@gmail.com (A.H.-G.) \\ * Correspondence: moumtaz.razack@univ-poitiers.fr
}

Received: 27 September 2019; Accepted: 6 November 2019; Published: 8 November 2019

\begin{abstract}
The Republic of Djibouti has an area of 23,000 km², a coastline $370 \mathrm{~km}$ long and a population of 820,000 inhabitants. It experiences an arid climate characterized by high daytime temperatures and low and irregular rainfall (average of $140 \mathrm{~mm} /$ year), resulting in continuous periods of drought. These difficult climatic conditions and the absence of perennial surface water have progressively led to an intensive exploitation of groundwater to meet increasing water demands in all sectors (drinking water, agriculture and industries). In coastal areas, seawater intrusion constitutes a significant additional risk of groundwater degradation. This study is focused on the coastal aquifer of Tadjourah which supplies water to the city of Tadjourah, currently comprising 21,000 inhabitants. The main objective of this work is to assess the current resources of this aquifer; its capacity to satisfy, or not, the projected water demands during coming years; and to analyze its vulnerability to seawater intrusion within the frame of climate change. Three RCPs (Representative Concentration Pathway) were used to simulate different climate scenarios up to 2100 . The simulated rainfall series allowed to deduce the aquifer recharge up to 2100 . The code Seawat was used to model seawater intrusion into the aquifer, using the recharge data deduced from the climate scenarios. The results indicate that the risk of contamination of the Tadjourah coastal aquifer by seawater intrusion is high. The long-term and sustainable exploitation of this aquifer must take into consideration the impact of climate change.
\end{abstract}

Keywords: coastal aquifer; modeling; Seawat; climate change; seawater intrusion; Tadjourah; Djibouti

\section{Introduction}

Water resources in coastal aquifers are intensely exploited given the widespread social and economic development of coastal areas around the world [1]. In these coastal areas, groundwater is often the only water resource of acceptable quality. When these areas are within arid to semi-arid climate, groundwater in this context is the only available water resource. This resource is crucial and unique [2-4] but is already under high pressure given the needs and demands that are constantly increasing [5-7]. As a result, coastal aquifers experience a very high exploitation of their resources, often leading to uncontrolled overexploitation, the consequences of which can be dramatic.

All coastal aquifers naturally undergo a saltwater intrusion, due to the difference in density between freshwater and saltwater [8,9]. When the water budget of coastal aquifers becomes unbalanced due to various causes (over-exploitation, recharge decrease due to climate change impact, etc.), the seawater wedge may significantly progress inland and contaminate the exploitation wells [10-14]. So the most important consequence of any lack of management of these aquifers is the degradation of the quality of the underground resources due to excessive seawater intrusion. In such cases, the lack 
of management can lead to a limitation of the exploitation of the coastal aquifers, even the cessation of the exploitation. In these regions, the impact of climate change combined with water scarcity and quality degradation are aggravating factors [15] and a serious threat to growth and stability of the regional social system. Effective management strategies are an imperative for optimal water use in coastal aquifers, in order to control seawater intrusion and respond to water demands in the framework of social and economic development of these coastal regions. For this purpose, numerical modeling of aquifers constitutes a critical tool [16] which permits to analyze the aquifers' reactions to various stresses.

This problem is analyzed based on the case of the coastal aquifer of Tadjourah located in the Republic of Djibouti (RoD), in the Horn of Africa. The RoD has an area of $23,000 \mathrm{~km}^{2}$, a coastline $370 \mathrm{~km}$ long and a population of 820,000 inhabitants (census 2009) (Figure 1). As generally is the case in Africa [17], population concentration is increasing in coastal areas in RoD. The RoD experiences an arid climate characterized by high daytime temperatures and low and irregular rainfall (average of $140 \mathrm{~mm} /$ year), resulting in continuous periods of drought. There is no perennial surface water. These difficult climatic conditions and the absence of perennial surface water have progressively led to an intensive exploitation of groundwater, with currently around 20 to 22 million $\mathrm{m}^{3}$ per year in 2015. Signs of such overexploitation are expressed by the drastic lowering of some groundwaters and the deterioration of their quality [4]. The coastal aquifer under study supplies water to the city of Tadjourah, currently comprising 21,000 inhabitants [18]. In the near future, the city of Tadjourah is expected to experience significant development, with a substantial increase in tourist, port and agricultural activities, with the result that water needs will be increasing considerably. The projections point to a doubling of water demand by 2030, compared to 2012 [18].
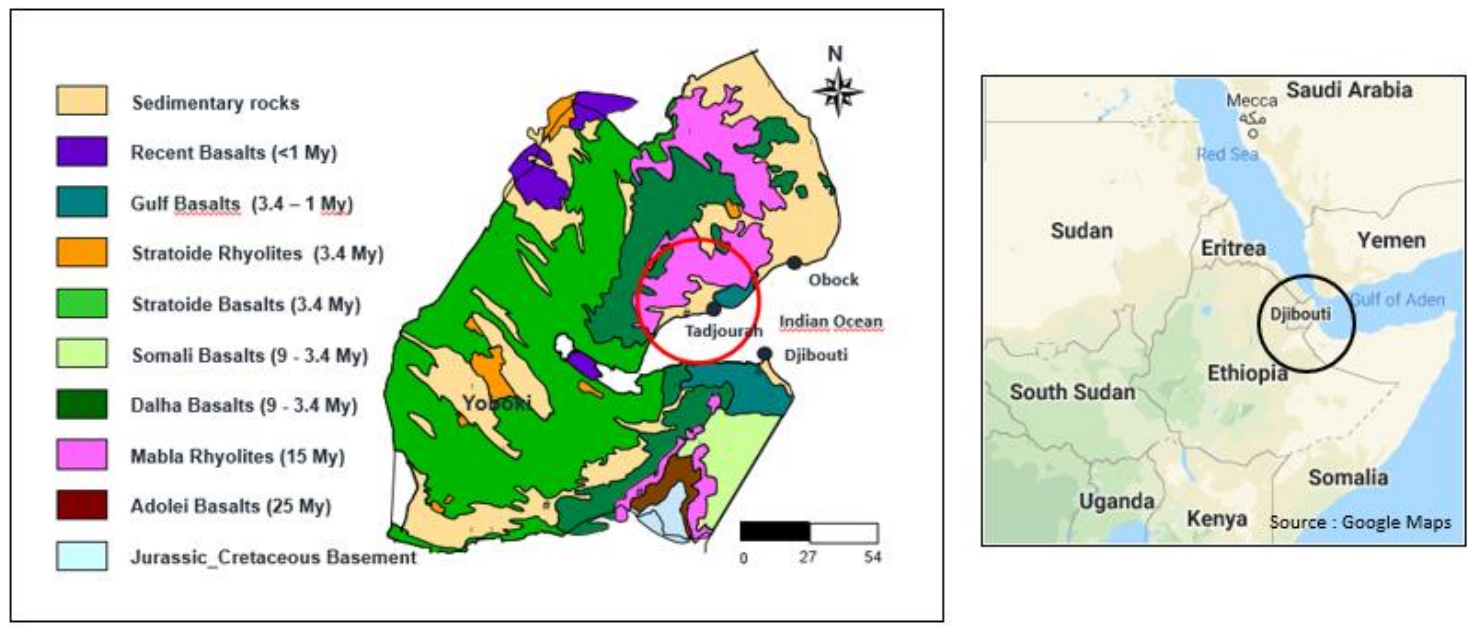

Figure 1. Location of the Republic of Djibouti and of the Tadjourah coastal aquifer.

The main objective of this work is to assess the current resources of this aquifer, its capacity to satisfy (or not) the projected water demands during coming years, and to analyze its vulnerability to seawater intrusion within the frame of climate change. The approach developed in this study can be broken down as follows:

- $\quad$ simulate rainfall series up to 2100 at the scale of RoD using climate scenarios made available by IPCC;

- deduce groundwater recharge based on the simulated rainfall series;

- model the studied aquifer, using the recharge series as the input;

- $\quad$ analyze the aquifer reaction to the climate scenarios. 


\section{Materials and Methods}

\subsection{Study Area}

\subsubsection{Geological Setting}

The geodynamic context of the RoD is marked by the separation of the tectonic plates of Arabia, Africa and Somalia delimited by the East African rifts, the Red Sea and the Gulf of Aden. The functioning of this system for 30 million years has set up many volcanic series. Given this geodynamic situation, volcanic rocks, consisting mainly of basalts and some rhyolitic formations, cover most of the territory $(80 \%)$, with sedimentary formations remaining small (Figure 1$)$. These two types of rock form aquifers whose water resources are intensively exploited to satisfy the needs of the country.

This work focuses on the alluvial aquifer Tadjourah, located on the north shore of the Gulf of Tadjourah. The coastal plain is spread over $30 \mathrm{~km}$ along the coast with a width varying between 2 and $6 \mathrm{~km}$ and has an area of about $80 \mathrm{~km}^{2}$. It is the largest coastal plain in the country after the Obock plain. To the south, it is bounded by the sea, to the north and west by the Goda Massif formed of Mabla rhyolites and Dalha basalts, and to the east by outcrops of recent basalts (Figure 2).

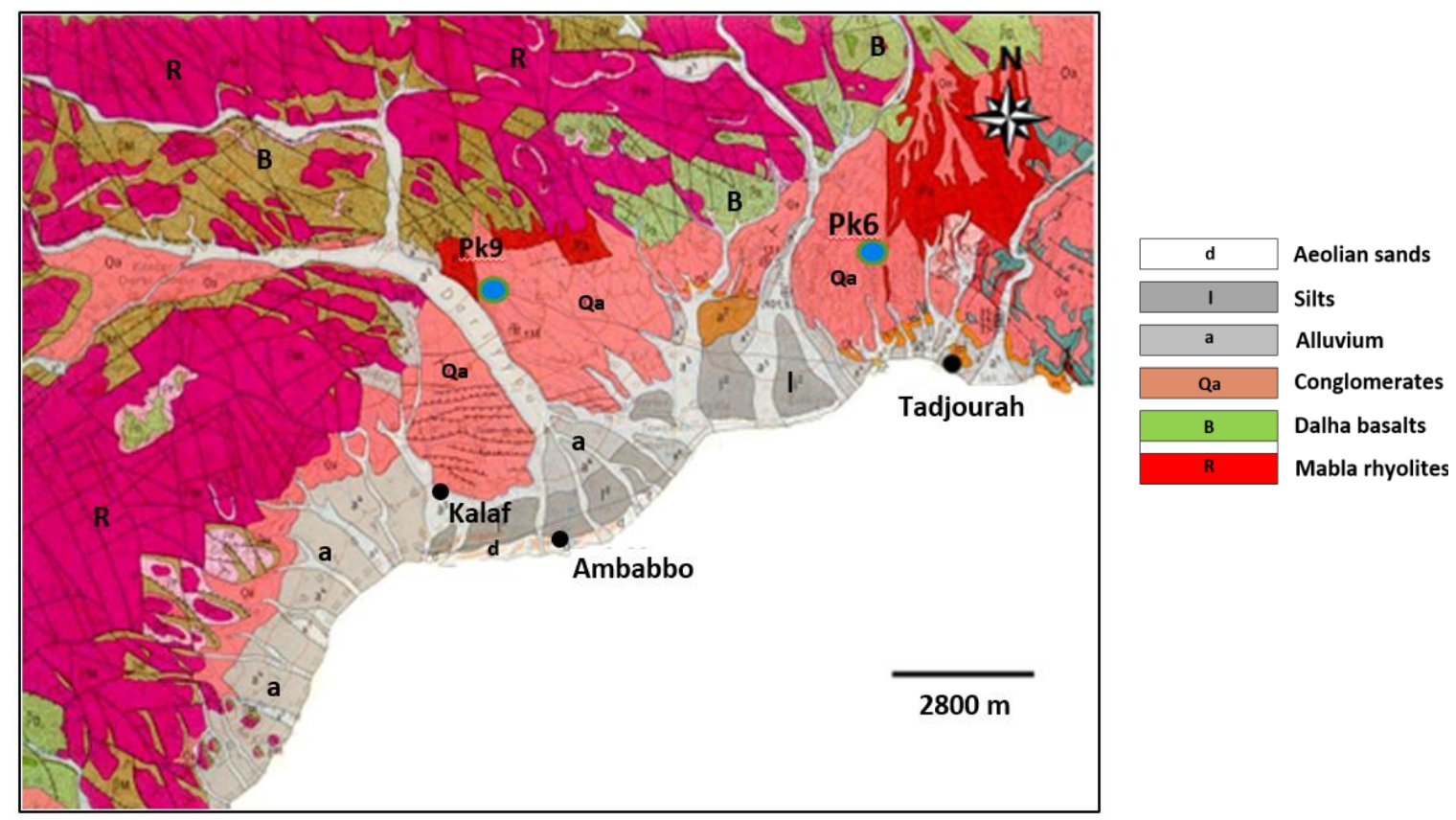

Figure 2. Geology of the coastal alluvial aquifer of Tadjourah. (Extracted from the geological map of the RoD at 1/100000. Tadjourah sheet [19]. d: Aeolian sands; a: alluvium; l: silt; Qa: Rhyolitic \& basaltic conglomerates. Pliocene-Middle Pleistocene; R: Mabla rhyolites; B: Dalha basalts).

The conglomerates, arranged in terraces at several levels, consist of coarse materials, sand and gravel. These conglomeratic formations, of Upper Pliocene to Middle Pleistocene, constitute the coastal aquifer of Tadjourah. The Goda Massif north of Tadjourah is the most watered area in the country, with an average of $200 \mathrm{~mm}$ rainfall per year. On the plain, the water points are spread over the coastal area and are clustered around Tadjourah, Ambabbo and Kalaf.

\subsubsection{Hydrography}

The plain of Tadjourah is drained by two main wadis: Dariyyou and Walwale (Figure 2). Wadi Dariyyou originates in the Goda Massif, draining peaks of nearly $1300 \mathrm{~m}$ altitude. After a course of $30 \mathrm{~km}$ it flows into the sea around Ambabbo with a delta of $4-5 \mathrm{~km}$ wide. The total watershed of this wadi is $185 \mathrm{~km}^{2}$ in area. Wadi Walwale has its source on the Dadar Massif at more than $1000 \mathrm{~m}$ 
of altitude and flows into the sea to the West of Tadjourah, by a delta of $5 \mathrm{~km}$ wide, after a course of more than $40 \mathrm{~km}$. The watershed of this wadi with an area of $215 \mathrm{~km}^{2}$ is, with that of Dariyyou, the origin of alluvial terraces characteristic of the plain. Between these two main alluvial cones, flows a series of small wadis with courses sub-parallel between them and originating on the surrounding mountains.

\subsubsection{Hydrogeology}

The aquifer is composed of coarse sediments consisting mainly of rhyolitic and basaltic conglomerates. The thickness of the sedimentary formations was determined by geoelectric surveys [20-22] validated using the lithological sections of the wells. As a result, the average thickness of alluvial formations is of the order of $200 \mathrm{~m}$. These formations are based on a substratum formed by volcanic formations. The contact between the sediments of the plain and the Goda Massif is constituted by a fault. Geophysical prospections also identified the freshwater-seawater interface in the Ambabbo sector. These investigations showed that the seawater intrusion is relatively important and could penetrate several hundreds of meters inland. The available piezometric data, collected when the aquifer is not in exploitation, allowed to map the groundwater flow (Figure 3). The piezometric map shows quite clearly that the aquifer is supplied from the upstream limit formed by the contact with the volcanic formations of Mount Goda. The geochemistry of the Tadjourah aquifer pointed out the relevance of inflow from the volcanic formations of the Goda mountains upstream of the plain [23]. Relatively high hydraulic gradients are displayed along the coastline.

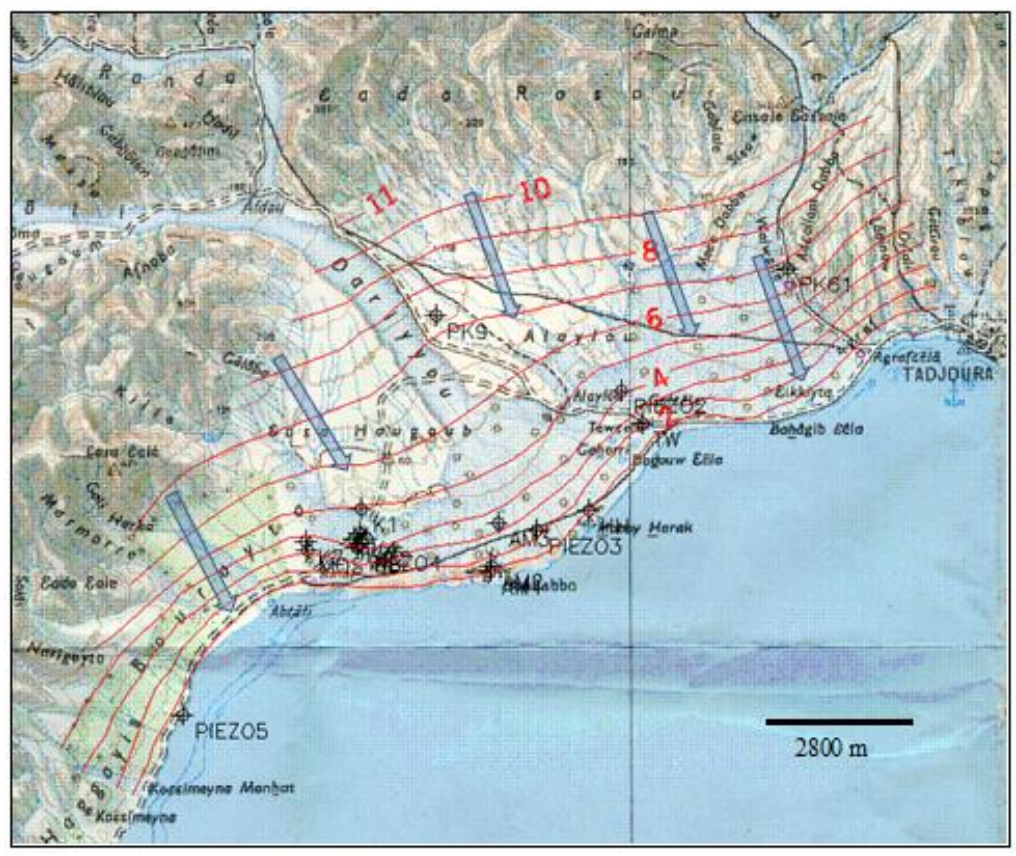

Figure 3. Piezometry of the alluvial coastal aquifer of Tadjourah when wells are not in exploitation.

A thorough analysis of aquifer recharge conditions in the RoD, done by the BGR (Bundesanstalt für Geowissenschaften und Rohstoffe, Germany [21]), showed that the average rate of infiltration to aquifers ranges between $3 \%$ to $5 \%$ of the raw precipitations. Due to the arid climate context, the losses by ET (Evapotranspiration) are very important. This essential outcome of the BGR was confirmed by later works [24-27]. Based on the results of the BGR, the CERD (Centre d'Etudes et de Recherche de Djibouti-Center for Studies and Research of Djibouti) was able to estimate some components of the water balance of the Tadjourah aquifer, including recharge and inputs from the upstream boundary [23] (Table 1). Recharge was estimated based on an average annual rainfall of $200 \mathrm{~mm}$. Inflow from the upstream boundary was estimated using the transmissivity of the volcanic rocks. 
Table 1. Components of the aquifer water balance estimated by the CERD [23].

\begin{tabular}{ccc}
\hline Component $\left(\mathrm{m}^{3} /\right.$ year) & Inflow & Outflow \\
\hline Surficial Recharge & $4.5 \times 10^{5}-6.5 \times 10^{5}$ & - \\
\hline Seashore & $?$ & $?$ \\
\hline Upstream Limit with Mount Goda & $1.8 \times 10^{6}-2.7 \times 10^{6}$ & - \\
\hline ?: These components of the water balance could not be estimated in the field.
\end{tabular}

As we are dealing with a coastal aquifer, the groundwater flow is of variable density and the seashore does not constitute a simple outflow boundary of the system because of seawater intrusion into the aquifer. Two components, outflow and inflow, should be differentiated on this boundary. Field estimation of these components is quite difficult as it would require equipment which are not available in the RoD (e.g., wells along the coastline drilled up to the aquifer bottom).

The transmissivity of the aquifer was estimated by pumping tests [23] at the wells PK6 and PK9 (Table 2). These transmissivity values $\left(\mathrm{T}, \mathrm{m}^{2} / \mathrm{d}\right.$ ) were used to derive the initial hydraulic conductivities $(\mathrm{K}, \mathrm{m} / \mathrm{d})$ for modeling purposes. The hydraulic conductivity field over the entire aquifer was determined by calibrating the numerical model. The storage parameters (storage coefficient $\mathrm{S}$, specific storage $\mathrm{Ss}$, porosity $n$ ) were estimated by reference to the literature and adjusted during calibration of the model.

Table 2. Transmissivity $\left(\mathrm{T}, \mathrm{m}^{2} / \mathrm{d}\right)$ and Hydraulic Conductivity $\mathrm{K}(\mathrm{m} / \mathrm{d})$ estimated by pumping tests at the wells PK6-5 and PK9-5 [16].

\begin{tabular}{ccc}
\hline Well & T (m $\left.{ }^{2} / \mathbf{d}\right)$ & K (m/d) \\
\hline PK6 & 216 & 1.1 \\
\hline PK9 & 605 & 3.0 \\
\hline
\end{tabular}

\subsubsection{Exploitation of the Aquifer}

The city of Tadjourah is supplied with water by the alluvial aquifer. The well Pk6, 3 kilometers from Tadjourah, is located on the cone of the Wadi Magalle-Walwallé. This well taps the aquifer at an average discharge rate of $1440 \mathrm{~m}^{3} / \mathrm{d}$, an average annual volume of $450,000 \mathrm{~m}^{3}$. Nine kilometers from Tadjourah, another well (Pk9), set up for the Tadjourah mineral water plant, is located on the high alluvial terraces of Wadi Dariyyou and exploits the aquifer at an average discharge of $1200 \mathrm{~m}^{3} /$ day. The cumulative volume abstracted on both wells amounts to approximately $960,000 \mathrm{~m}^{3} /$ year.

The exploitation of this aquifer raises the question of the sustainability of the resource, conditioned in particular by the equilibrium of the freshwater-seawater interface. This condition is vital to avoid degradation of the quality of groundwater by seawater intrusion, which may be caused by over-exploitation of the resource and/or by a change in climatic factors.

\subsubsection{Meteorological Data}

The most complete meteorological data set is measured at the DIA station (Djibouti International Airport). Annual precipitation values over the period 1961-2014 are shown in Figure 4 and the statistics in Table 3.

Table 3. Descriptive statistics of the series of annual precipitation values. SD: Standard Deviation, CV:

Coefficient of Variation, CA: Coefficient of Asymmetry.

\begin{tabular}{cccccc}
\hline & Min (mm) & Max (mm) & Average (mm) & SD (mm) & CV (\%) \\
\hline Whole series 1961-2014 & 3 & 481 & 146 & 122 & 84 \\
\hline Subseries 1961-2006 & 3 & 481 & 156 & 121 & 77 \\
\hline Subseries 2007-2014 & 3 & 89 & 44 & 28 & 65 \\
\hline
\end{tabular}




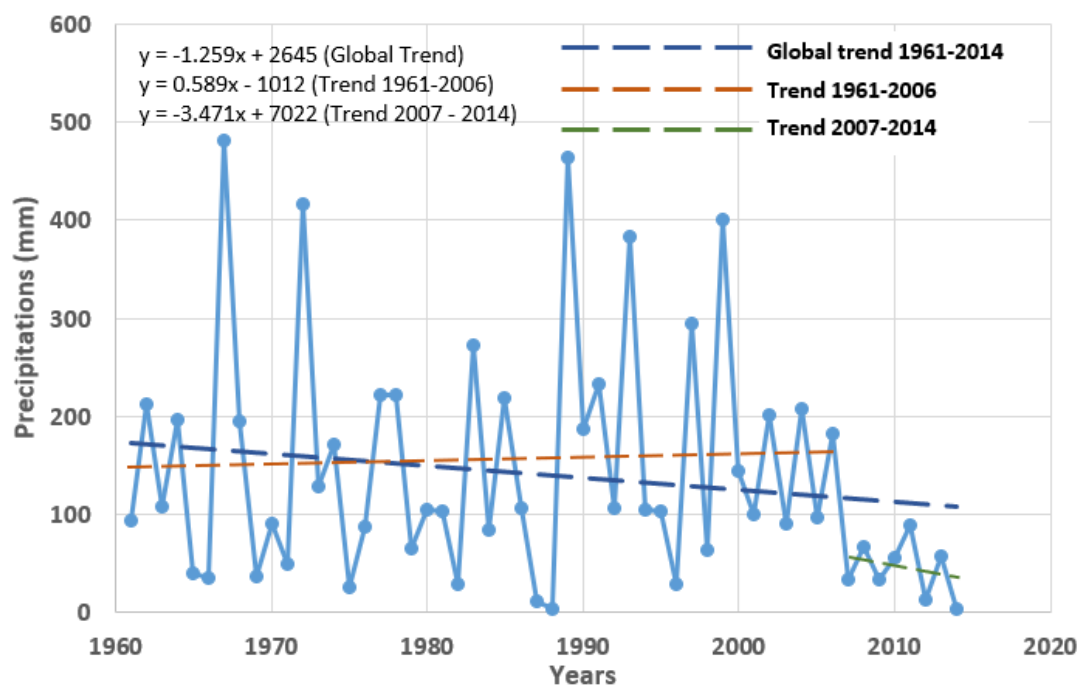

Figure 4. Annual precipitation and adjusted linear models over the whole period (1961-2014) and two sub-periods, 1961-2006 and 2007-2014 (Djibouti International Airport Station).

The minimum value of the annual rainfall ( $3 \mathrm{~mm} / \mathrm{year}$ ) is very low, showing that the RoD has drastic dry years. The maximum value is $483 \mathrm{~mm} /$ year. The coefficient of variation of the whole series is $84 \%$, revealing a strong inter-annual variability of the precipitation. The downward trend in precipitation is well marked in Figure 4, when considering the whole series.

The series can be divided in two segments 1961-2006 and 2007-2014, the last 8 years depicting a dramatic decrease in rainfall. Statistics of these sub-series are given in Table 2. These sub-series trend lines are shown in Figure 4. Paradoxically, the trend line of the period 1961-2006 shows a slight increase in precipitation. This positive trend in precipitation is caused by a few extreme high rainfalls. These extreme events in rainfall, which reverse the general downward trend, were noted in other areas under arid/semi-arid climate, like Algeria [28]. The role of such extreme events in enhancing groundwater recharge in arid/semi-arid environments has been commented on in several studies [29-32]. Accordingly, these extreme events should be taken into account as their role in groundwater recharge in an arid context can be significant.

The temperature data show a marked upward trend (Figure 5).

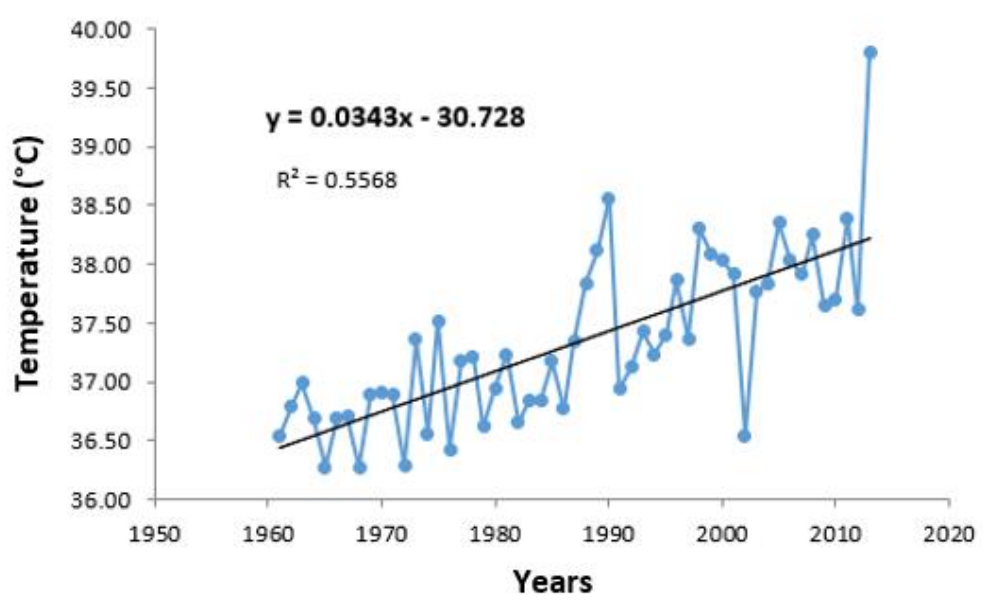

Figure 5. Annual averages of maximum temperature measured at the DIA station.

\subsection{Climate Change Scenarios}

In general, climate predictions $(\mathrm{P}, \mathrm{T})$ are established at large scales using global climate models (GCMs) that incorporate the components required for climate representation: (i) Atmospheric 
component; (ii) Oceanic component; and (iii) External components (forcings) to the climate system: greenhouse gases and aerosols. This last component (forcings) is uncertain because it is linked to human activities. Several climate scenarios were thus elaborated based on projected greenhouse gases emissions. The issue of uncertainty associated with the global scenarios is widely debated in the literature related to Water Sciences [33-36].

On a global scale, it is difficult to consider local weather phenomena. However, scenarios on future climate change at the local level are essential for socio-economic actors to conduct impact studies of climate change (hydrology, agriculture, ...). There are different methods of downscaling that can reduce the results of GCMs (Global Climate Models) to a finer scale. These results can then be used in climate change impact studies. In this study, the downscaling of global climate scenarios at the RoD scale was done in collaboration with the IGAD-CPAC (Inter-Governmental Authority on Development-Climate Prediction and Application Center) in Nairobi (Kenya).

Three RCPs (Representative Concentration Pathway) scenarios for the evolution of greenhouse gas concentration in the 21st century (RCP2.6, RCP4.5, RCP8.5) were simulated. A RCP scenario is used to model the future climate. In AR5 (IPCC 5th Assessment Report, [37]), based on different hypotheses concerning the quantity of greenhouse gases that will be emitted in the coming years (period 2000-2100), each RCP scenario gives a probabilistic variant of the climate that would result from the emission level chosen as the working hypothesis. The statistics of the three scenarios are reported in Table 4.

Table 4. Annual rainfall statistics predicted by climate scenarios RCP 2.6, RCP 4.5 and RCP 8.5. CI: Confidence Interval; SD: Standard Deviation.

\begin{tabular}{cccc}
\hline Scenario & RCP 2.6 & RCP 4.5 & RCP 8.5 \\
\hline Average $(\mathrm{mm})$ & 243.7 & 245.3 & 263.8 \\
CI $(95 \%)$ & $224<\mathrm{m}<263$ & $224<\mathrm{m}<265$ & $242<\mathrm{m}<285$ \\
\hline Minimum $(\mathrm{mm})$ & 91.7 & 102.2 & 111.3 \\
\hline Maximum $(\mathrm{mm})$ & 841.2 & 758.8 & 716.3 \\
\hline SD $(\mathrm{mm})$ & 100.6 & 105.1 & 108.9 \\
\hline CV $(\%)$ & 41.3 & 42.8 & 41.3 \\
\hline
\end{tabular}

These results show that statistically the three scenarios are comparable. The statistics remain close for the three scenarios. In particular, the arithmetic averages of the three scenarios show no significant difference (the confidence intervals overlap widely). The simulated maximums are very high for the three scenarios. The results of the three scenarios are shown in Figure 6. It can be noted that all the three scenarios generate very exceptional rains greater than $500 \mathrm{~mm}$ (return period $>100$ years).

The trends (linear model) calculated on the results of the three scenarios show a slight decrease for the RCP 2.6 scenario. On the other hand, there is an upward trend for scenarios 4.5 and 8.4. Such a paradoxical trend in the context of the RoD is caused by the exceptional rains generated by these scenarios. The maximum rainfall observed during 1961 to 2014 is $481 \mathrm{~mm} /$ year. Scenario RCP 2.6 generates a single exceptional annual rainfall $(P=820 \mathrm{~mm}$ in 2088), while scenarios RCP 4.5 and RCP 8.5 generate several such exceptional annual rainfalls.

As exceptional rain events have a significant role in the recharge of arid zone aquifers, the climate scenarios (RCP 4.5 and RCP 8.6) generating several extreme episodes have not been retained. The scenario RCP 2.6, generating a single extreme episode, was used in forthcoming modeling. The recharge series deduced from the rainfall series simulated under the scenarion RCP 2.6. was used in the numerical simulation of the Tadjourah coastal aquifer to analyze the impact of climate change. The code used in this study to model the aquifer is the SEAWAT code. This approach which combines climate scenarios and hydrologic models is more and more applied to assess the future behaviour 
of groundwater [38-41] as groundwater requirements for drinking, agriculture and industrial uses are dramatically increasing worldwide.
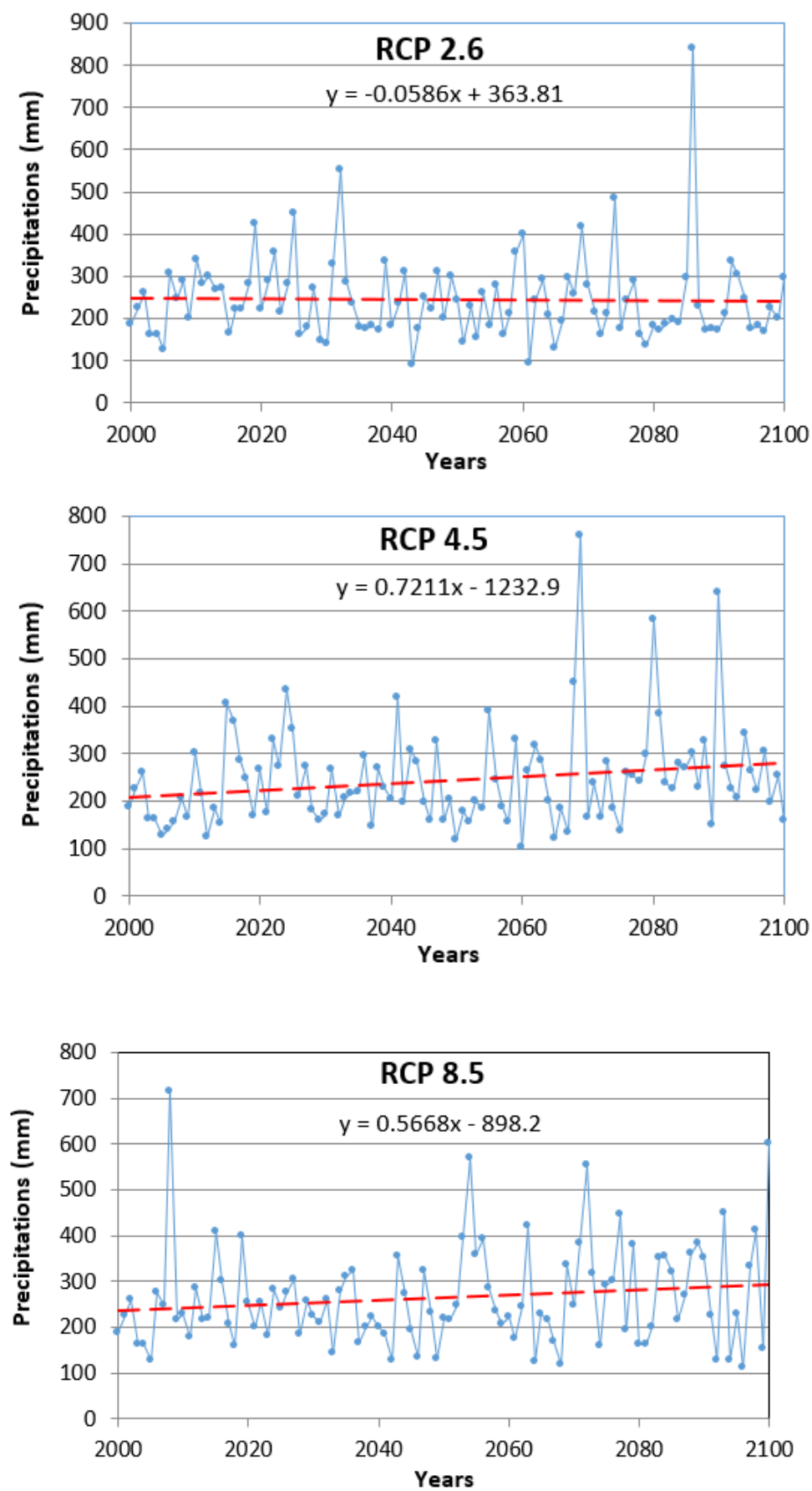

Figure 6. Results of the predictions of the three climate scenarios RCP 2.6, RCP 4.5 and RCP 8.5.

\subsection{The SEAWAT Software}

The coastal Tadjourah aquifer has been modeled using Seawat software [42]. Seawat is used to simulate three-dimensional, variable-density, transient ground-water flow in porous media. It was designed by combining the well-known flow code Modflow [43] and mass-transport code MT3DMS [44] to solve the coupled flow and solute-transport equations. The code uses the concept of Equivalent Freshwater Head in a groundwater salted environment. A thorough description of this concept 
is provided by the authors of this code [42]. Briefly, at any point $\mathrm{N}$ in the $3 \mathrm{D}$ salted groundwater environment, the freshwater head is defined as:

$$
h_{f}=\frac{P_{N}}{\rho_{f} g}+Z_{n}
$$

where $h_{f}$ is equivalent freshwater head $(L), P_{N}$ is pressure at point $N\left(\mathrm{ML}^{-1} \mathrm{~T}^{-2}\right), \rho_{\mathrm{f}}$ is density of freshwater $\left(\mathrm{ML}^{-3}\right), \mathrm{g}$ is acceleration due to gravity $\left(\mathrm{LT}^{-2}\right)$, and $\mathrm{ZN}$ is elevation of point $\mathrm{N}(\mathrm{L})$. At the same point $\mathrm{N}$, the actual head expressed in terms of the salted aquifer is written:

$$
\mathrm{h}=\frac{\mathrm{P}_{\mathrm{N}}}{\rho \mathrm{g}}+\mathrm{Z}_{\mathrm{n}}
$$

where $h$ is head $(\mathrm{L})$, and $\rho$ is density of saline groundwater at point $\mathrm{N}\left(\mathrm{ML}^{-3}\right)$. Flow and mass transport equations are written in SEAWAT in terms of equivalent fresh water (see [42]). Solving these equations provides solutions in terms of equivalent fresh water. Conversion is required between field data $(\mathrm{h})$ and equivalent fresh data and can be made with the use of the following expressions:

$$
h_{\mathrm{f}}=\frac{\rho}{\rho_{\mathrm{f}}} \mathrm{h}-\frac{\rho-\rho_{\mathrm{f}}}{\rho_{\mathrm{f}}} \mathrm{Z} \text { and } \mathrm{h}=\frac{\rho_{\mathrm{f}}}{\rho} \mathrm{h}_{\mathrm{f}}+\frac{\rho-\rho_{\mathrm{f}}}{\rho} \mathrm{Z}
$$

where $\mathrm{Z}$ is elevation ( $\mathrm{L}$ ). These equations are obtained by eliminating pressure between Equations (1) and (2) and solving for the respective head value [42]). The Seawat code has been successfully used to simulate and solve the issue of seawater intrusion in freshwater aquifers in many cases worldwide [45-52].

\section{Results and Discussions}

\subsection{Conceptual Model of the Aquifer}

The alluvial aquifer of Tadjourah is unconfined, characterized by an unsaturated zone and a saturated zone constituting the groundwater. The groundwater is of variable density, given the seawater intrusion. The top of the aquifer is represented by the topographic surface of the plain. An ASTER DEM, with a resolution of $90 \mathrm{~m} \times 90 \mathrm{~m}$, was used to obtain this topography. An average value of $200 \mathrm{~m}$, derived from geophysical prospecting, was used to represent the thickness of the aquifer. Numerical models of coastal aquifers are 3D multi-layered models to simulate seawater intrusion. They are thus discretized jointly on the horizontal and vertical planes. Vertical discretization is performed at a finer scale than horizontal discretization in order to correctly simulate seawater intrusion. In the case of the Tadjourah aquifer, the discretization scales are as follows: (i) For the horizontal discretization, the precision of the ASTER DEM has been kept, i.e., elementary cells of dimensions $90 \mathrm{~m} \times 90 \mathrm{~m}$; (ii) For vertical discretization, a cell height of $10 \mathrm{~m}$ was selected, except for the first layer of the model, whose top is represented by the topographic surface. The model has 18 layers and is discretized with a total of 109,441 cells. The boundary conditions (BC) are shown in Figure 7: (i) The contact with Mount Goda in layer 1 is represented by an inflow BC. For layers 2 to 18 , the upstream BC is also an inflow BC; (ii) the downstream limit with the sea is a fixed head $\mathrm{BC}$ (sea level) and constant concentration $\mathrm{BC}\left(35 \mathrm{~kg} / \mathrm{m}^{3}\right)$; (iii) the lateral limits are represented by no flow BCs and correspond to flowlines. The wadis, given their particularity (intermittent streams), are integrated as recharge areas. Figure 8 shows a NS vertical section through the model. 


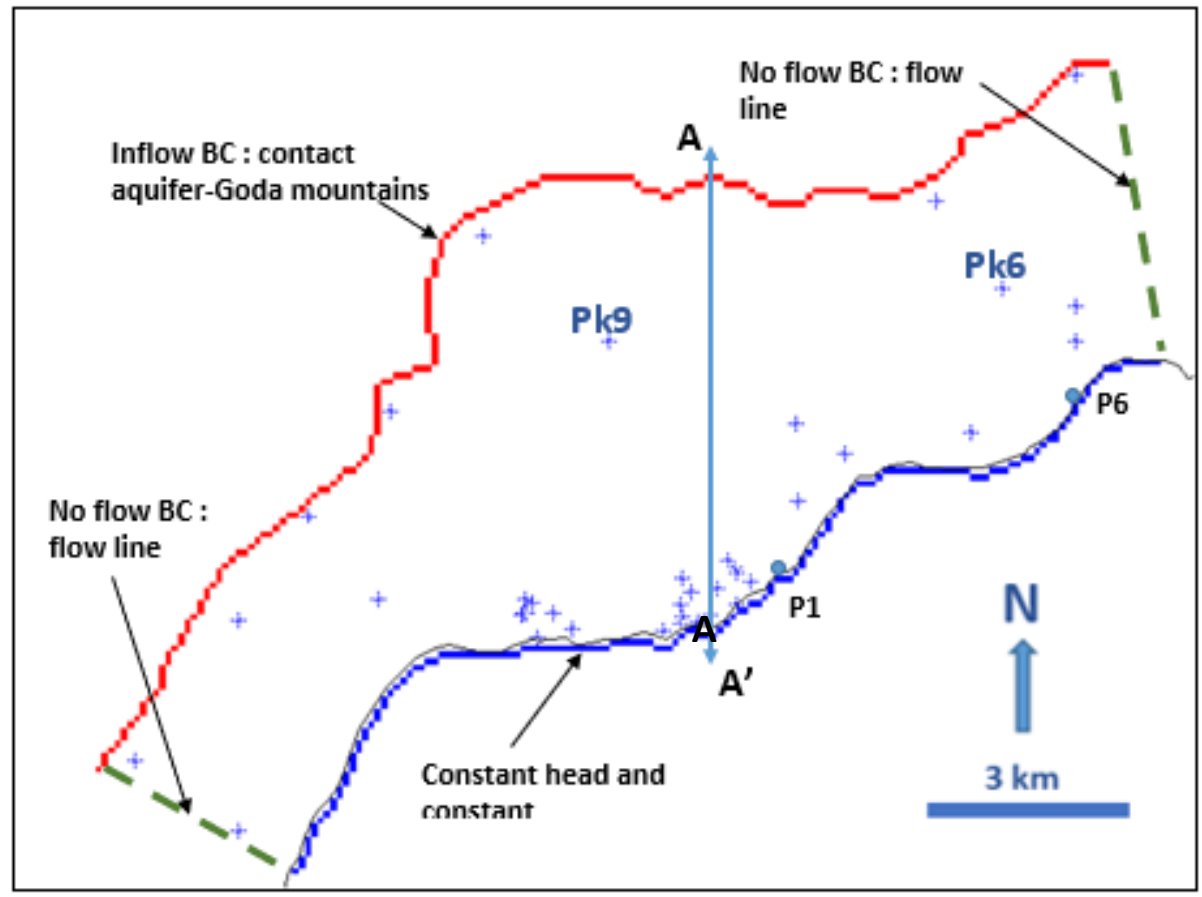

Figure 7. Boundary conditions of the numerical model of Tadjourah aquifer.

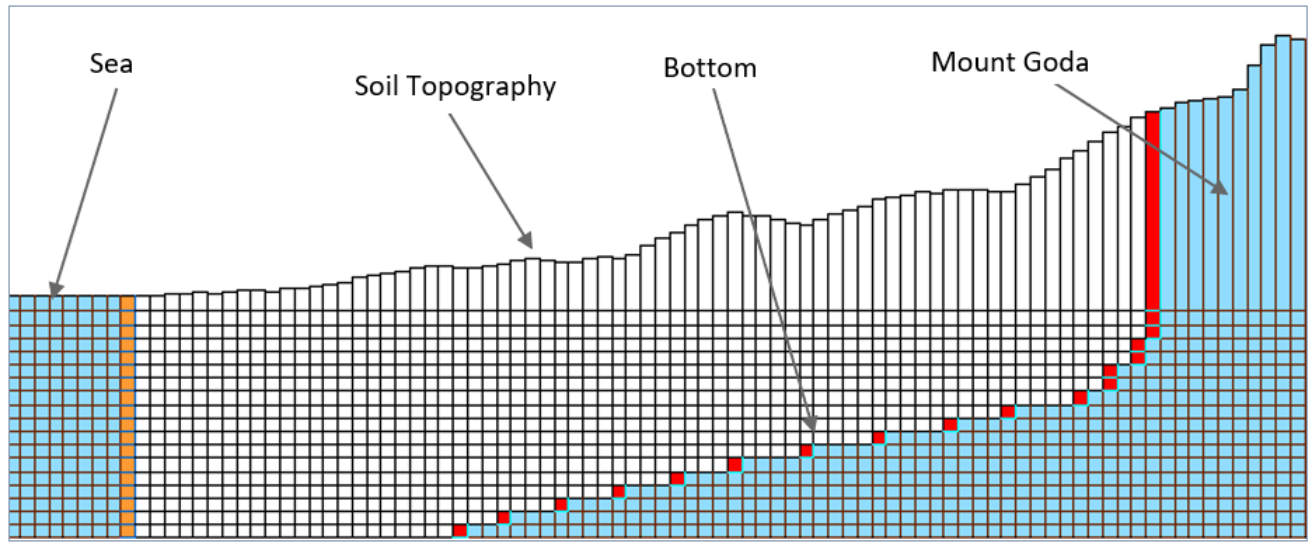

Figure 8. NS cross-section AA' showing the discretization of the model. (Exaggerated vertical scale $\times 5$ ).

\subsection{Calculation of the Equilibrium State}

An equilibrium state of the freshwater-saltwater interface was first sought corresponding to the situation prevailing before exploitation of the wells Pk6 and Pk9. The equilibrium state of the freshwater-saltwater interface was investigated by introducing zero initial concentration throughout the aquifer and running the model over a long period of time (100 years) to reach a steady state of concentrations in the aquifer. Two fictitious monitoring piezometers, P1 and P6 (Figure 7), were placed near the coast along flowlines passing by PK6 and PK9 wells to follow the evolution of the concentrations in the aquifer. The diagrams Concentration vs. Time below (Figure 9) show the evolutions of the concentrations on these piezometers in the first layer of the model.

It is plausible to consider that equilibrium is reached as the concentration stabilizes at P1 and P6 piezometers located very close to the shore. The concentrations can still evolve because of dispersion/diffusion phenomena, but do not call into question the freshwater-saltwater equilibrium. The wells Pk6 and Pk9 are not affected. 

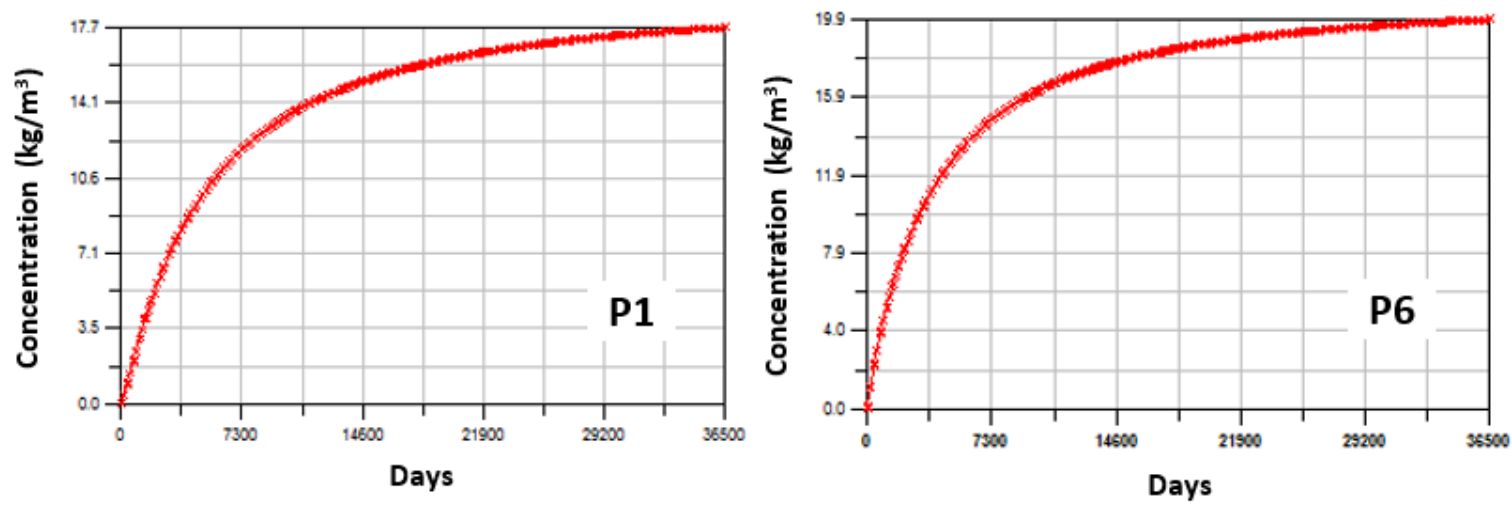

Figure 9. Simulated concentration change in P1 and P6 piezometers during the freshwater-saltwater equilibrium research phase.

The simulated piezometry related to this pseudo-steady equilibrium status and the water balance of the aquifer are shown in Figure 10 and Table 5 respectively. The simulated piezometry corresponds well to the observed piezometry. In particular, the gradients are well respected. The high gradients existing near the shore are correctly simulated. For further evaluation of the model calibration, additional measures [52] are provided in Appendix A: The scatterplot of measured heads vs. simulated heads (Figure A1), the determination coefficient $\left(R^{2}\right)$, the mean error (ME), the mean absolute error (MAE), and the root mean squared error (RMSE) (Table A1). The frequency distribution of the errors is given in Figure A2. The determination coefficient is high $\left(R^{2}=0.94\right)$ indicating that measured and simulated heads are well correlated. Values of other calibration measures $(\mathrm{ME}=0.16 \mathrm{~m} ; \mathrm{MAE}=0.45 \mathrm{~m}$; RMSE $=0.54 \mathrm{~m}$ ) indicate that the average error in calibrating the model is low. The distribution diagram (Figure A2) shows that the errors are random. Overall, the model is quite well calibrated on the observed general flow pattern.

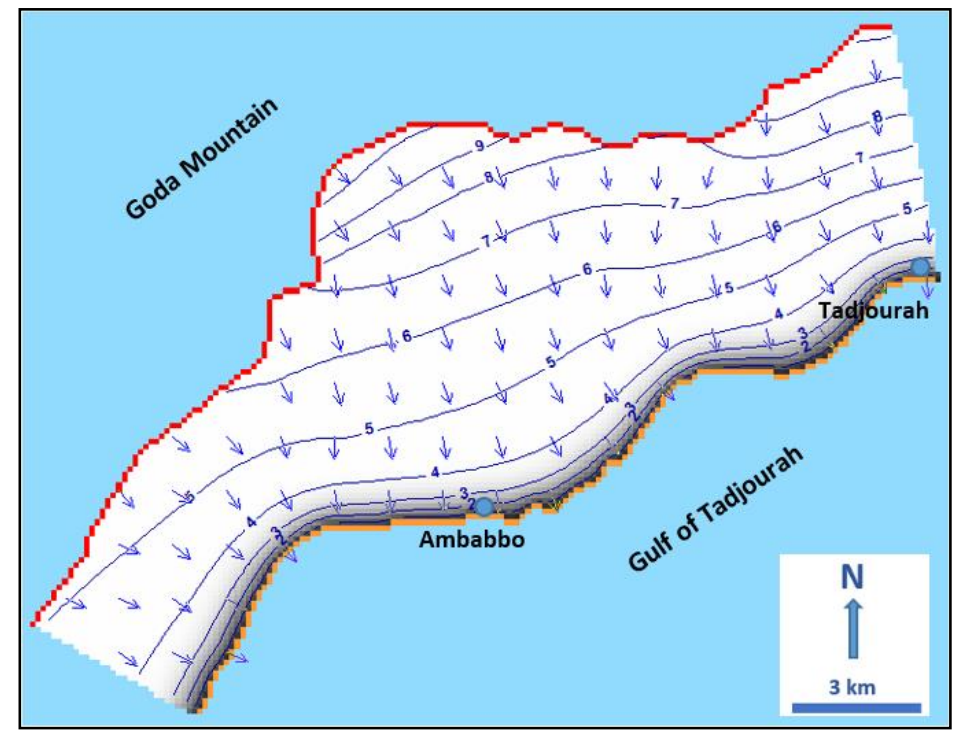

Figure 10. Simulated piezometry corresponding to the equilibrium state of the seawater intrusion.

The annual surface recharge represents a volume of $648,000 \mathrm{~m}^{3} /$ year which is in adequation with field estimation (see Table 1). The average annual rainfall over the Tadjourah aquifer in 2000 is $182 \mathrm{~mm} /$ year. The recharge therefore represents a rate of $4.9 \%$ of the average annual precipitation. This is in the order of magnitude of the estimates for other areas of the RoD. The upstream limit inflow is $2.26 \times 10^{6} \mathrm{~m}^{3} /$ year and agrees with field estimation (see Table 1). This component contributes significantly to the aquifer water balance. The inflows and outflows on the boundary corresponding to the sea, caused by the 
difference in density, are well differentiated in this water balance. The groundwater is in pseudo-steady state (Sum of the inputs \# sum of the outputs).

Table 5. Annual water balance of the aquifer, simulated by the model and corresponding to the equilibrium state of the seawater intrusion.

\begin{tabular}{cccc}
\hline Component $\left(\mathbf{m}^{3} /\right.$ year) & Inflow & Outflow & Inflow-Outflow \\
\hline Surficial Recharge & $6.48 \times 10^{5}$ & & $6.48 \times 10^{5}$ \\
\hline Limit corresponding to the sea & $1.41 \times 10^{6}$ & $4.27 \times 10^{6}$ & $-2.86 \times 10^{6}$ \\
\hline Upstream Limit with Mount Goda & $2.26 \times 10^{6}$ & & $2.26 \times 10^{6}$ \\
\hline Storage & $4.88 \times 10^{2}$ & $1.42 \times 10^{4}$ & $-1.37 \times 10^{4}$ \\
\hline TOTAL & $4.32 \times 10^{6}$ & $4.29 \times 10^{6}$ & $3.14 \times 10^{4}$ \\
\hline
\end{tabular}

Figure 11 shows the status of this interface in the aquifer in the Ambabbo area. The aquifer is contaminated by seawater for several hundred meters inland, which is consistent with the results of the geophysical survey [22]. One should keep in mind that this equilibrium state is calculated in the absence of any exploitation of the aquifer. Areas of PK6 and PK9 wells are not affected by seawater intrusion.

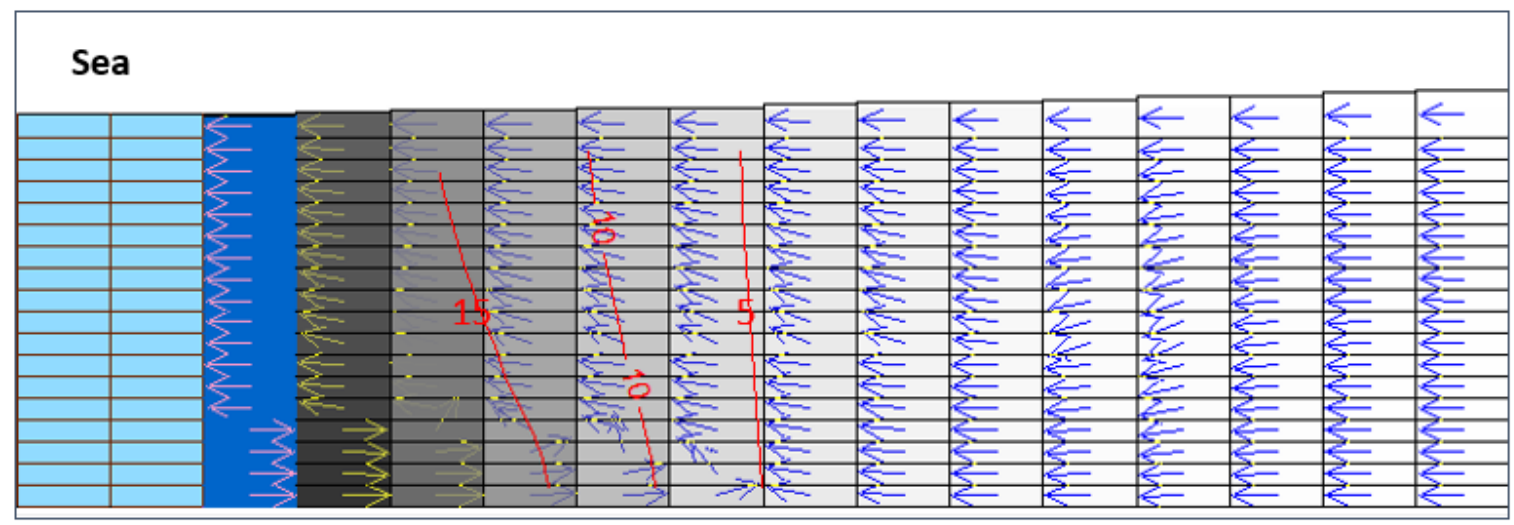

Figure 11. Simulated state of equilibrium of the seawater intrusion in the area of Ambabbo. NS vertical cross-section. Concentration in $\mathrm{kg} / \mathrm{m}^{3}$.

Adding the inflow through the upstream boundary and the surface recharge gives an average annual renewable resources of this aquifer of: 2,910,000 $\mathrm{m}^{3} /$ year. Present water requirements, as stated above, amount on average to $960,000 \mathrm{~m}^{3} /$ year, which represent $33 \%$ of the aquifer renewable resources. This ratio is reasonable and theoretically the aquifer has the potential to provide such a quantity of water without being in a state of overexploitation. However, the impact of climate change must be taken into account before drawing any conclusion regarding the sustainability of the aquifer.

\subsection{Simulation of Climate Change Impact up to 2100 under RCP Scenarios 2.6, 4.5 and 8.5.}

The exploitation rates of the aquifer at the wellfields Pk6 and Pk9 were kept constant throughout the simulation period 2001 to 2100 . The objective is therefore to test the sustainability of the exploitation of the aquifer at these exploitation rates: $\mathrm{Pk} 6$ at $1440 \mathrm{~m}^{3} / \mathrm{d}$ and $\mathrm{Pk} 9$ at $1200 \mathrm{~m}^{3} / \mathrm{d}$.

The concentration evolution from 2001 to 2100, on piezometers P1, P6 (100m from the coast), and at the wells Pk9 and Pk6 are represented in Figures 12 and 13 for RCP 2.6, in Appendix B for RCP 4.5 (Figures A3 and A4) and Appendix C for RCP 8.5 (Figures A10 and A11). Under all three scenarios, near the coast (P1 and P6 piezometers), the concentration trend is increasing in both piezometers and the seawater intrusion continues to advance during the simulation period (2001-2100), over the entire height of the aquifer (Figures 12, A3 and A10). There is no stabilization of the concentrations. The well 
Pk9 remains untouched (Figures 13, A4 and A11). The well Pk6 is affected by saltwater contamination. The concentration trend is increasing at this well and its value at the end of the simulation time is about $18 \mathrm{~g} / \mathrm{m}^{3}$ under all scenarios.
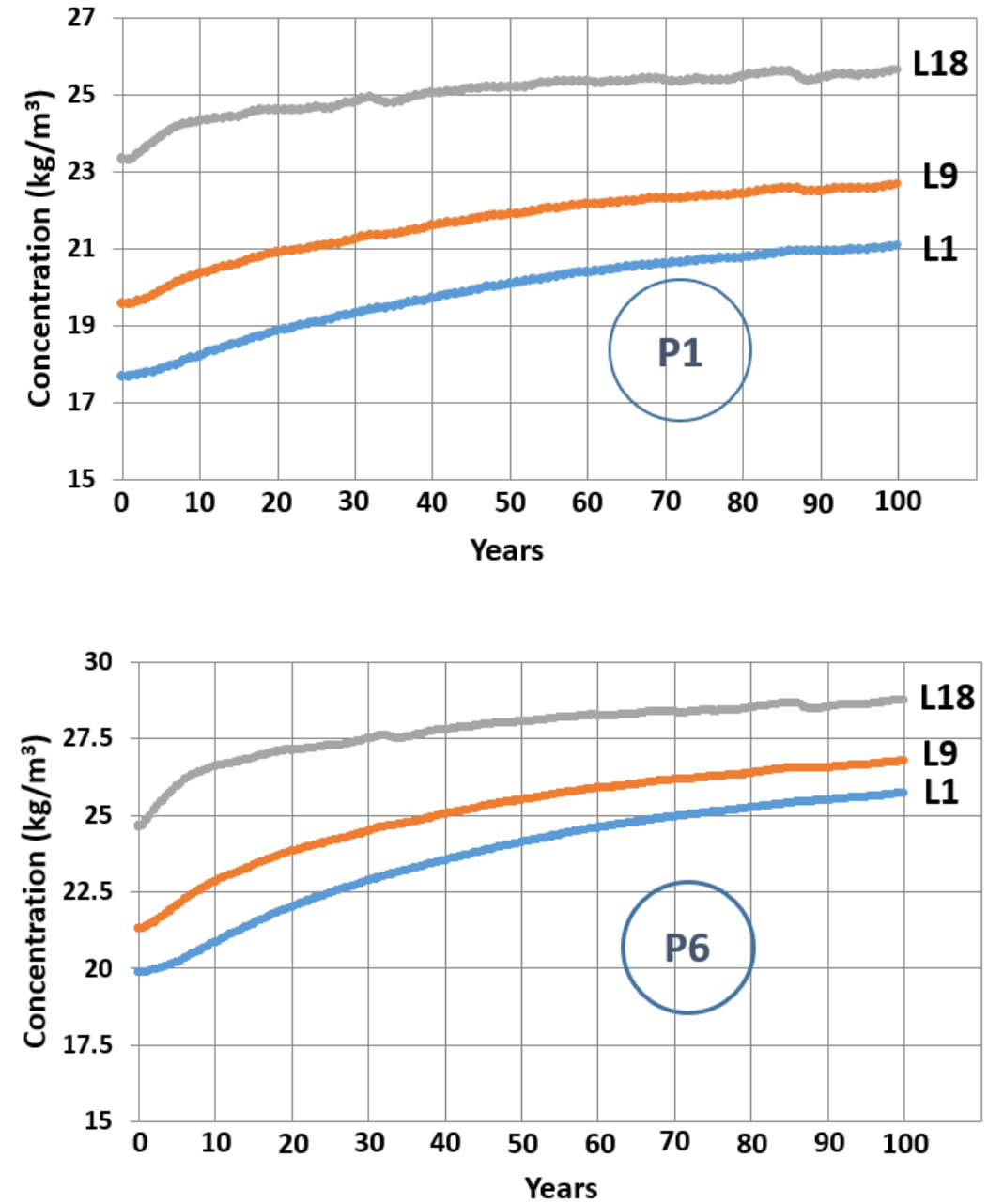

Figure 12. Concentrations variation at monitoring piezometers P1 and P6 (100 m from the coast) under RCP scenario 2.6. L1: layer 1; L9: layer 9; L18: layer 18.

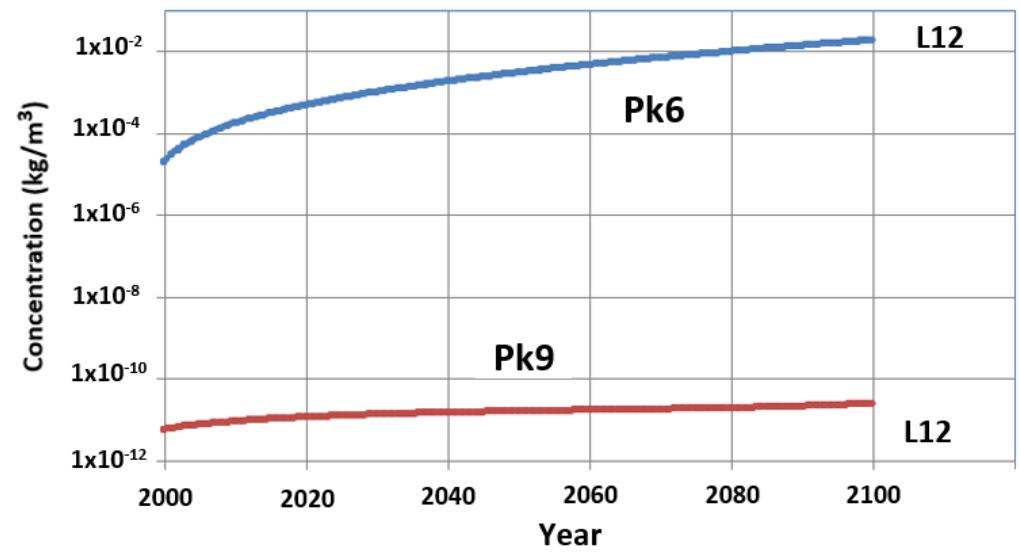

Figure 13. Concentrations variation at wells Pk6 and Pk9 under RCP scenario 2.6.

Piezometric variations at Pk9 and Pk6 are shown in Figure 14 (RCP 2.6), B3 and C3 (scenarios RCP 4.5 and 8.5 ). In both wells, the pumping provokes a large drawdown at the beginning of the simulation. 
Impacts of the exceptional rainfalls simulated in each scenario are clearly depicted in these figures, as they provoke significant piezometric rising. However, the drawdowns tend towards a stabilization at both wells under all three scenarios. At the end of the simulation time, the hydraulic head at both sites is low and is only a few meters above sea level ( $3 \mathrm{~m}$ at Pk9 and $<1 \mathrm{~m}$ at Pk6). All three scenarios lead to the same conclusion. It is clear that under these conditions, no increase in the exploitation of the groundwater can be recommended.

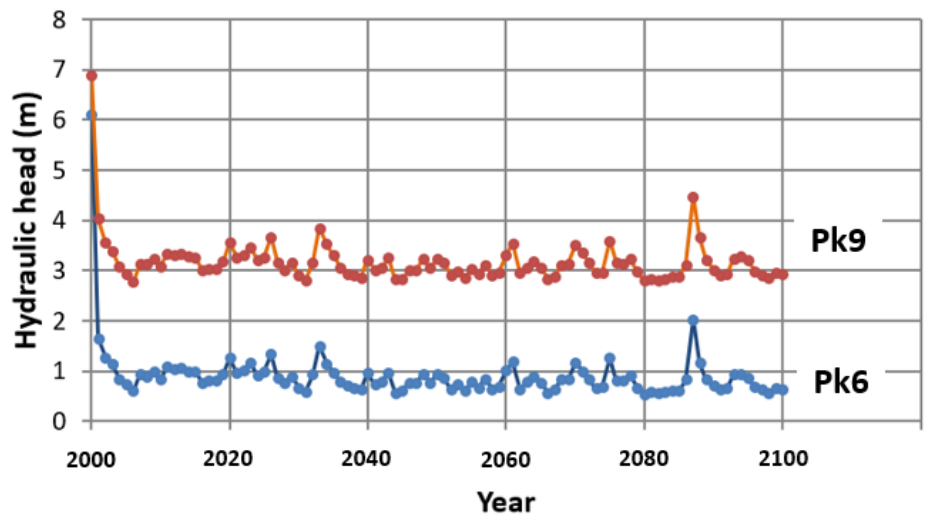

Figure 14. Piezometric variations at wells Pk9 and Pk6 from 2001 to 2100 under scenario RCP 2.6.

The variation of the aquifer reserves and the balance inputs/outputs on the coastline are shown in Figures 15 and 16 (RCP 2.6), B4 and B5 (RCP 4.5), and C4 and C5 (RCP 8.5). Under all three scenarios, the reserves fluctuate around zero value, showing that the aquifer is not in permanent destocking situation. Reserves are stored during exceptional recharge episodes but run out quickly. Figure 16 shows that the inputs/outputs that occur on the coast, which are caused (in part) by the difference in density between freshwater and saltwater, play an important role in the variation of the aquifer reserves. The same remark can be drawn from Figure A7 (RCP 4.5) and C5 (RCP 8.5). The situation of the seawater intrusion in 2100, in the area near Ambabbo, is reproduced in Figure 17 (RCP 2.6), B6 (RCP 4.5), C6 (RCP 8.5). Comparing these Figures with Figure 11, clearly shows that the seawater intrusion worsened during the period 2001-2100. In all three scenarios, the penetration of the deep salted wedge marks an advance inland of more than $300 \mathrm{~m}$. The groundwater piezometry in 2100 and the concentration at the surface (Layer 1) are reproduced in Figure 18 (RCP 2.6), B7 (RCP 4.5), and C7 (RCP 8.5). The piezometric depressions due to pumping are well evidenced. The seawater intrusion at the surface also appears clearly under the three scenarios.

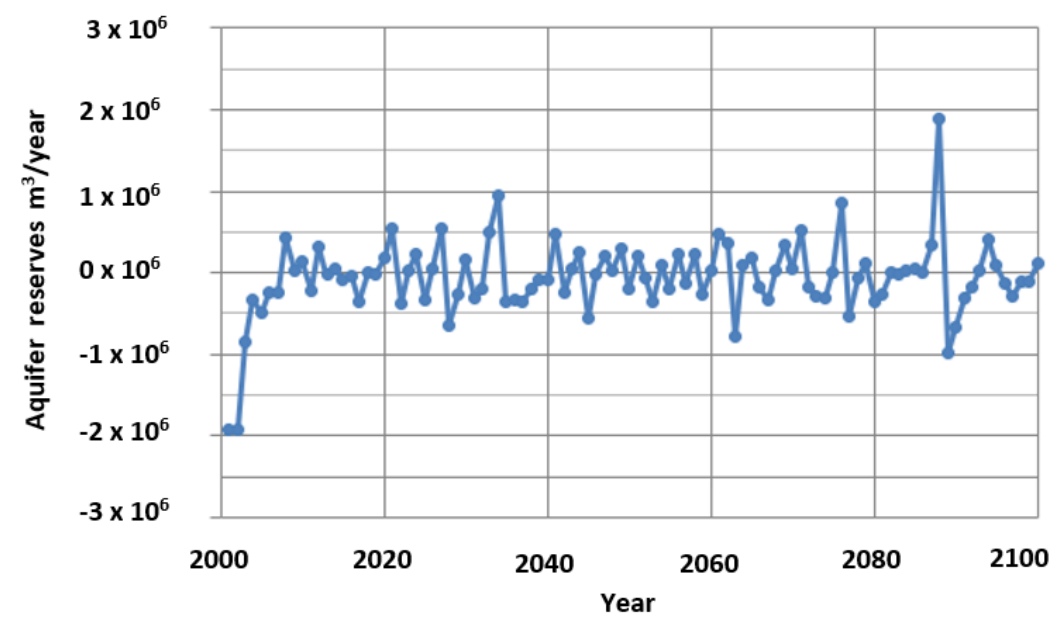

Figure 15. Changes in aquifer reserves from 2001 to 2100 under the RCP 2.6 scenario. 


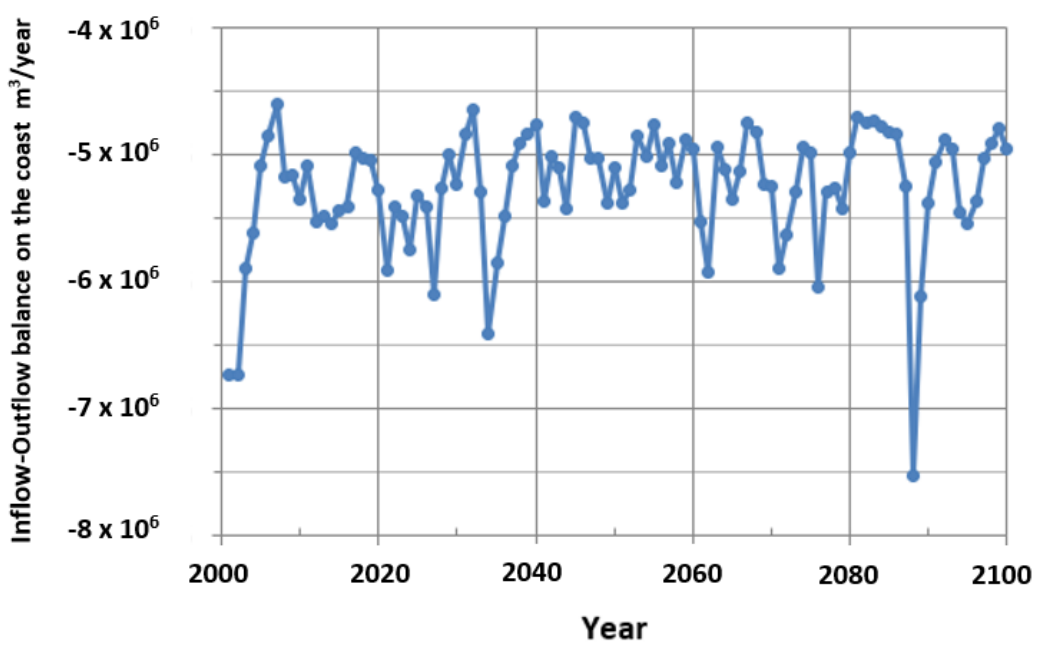

Figure 16. Inputs/Outputs balance on the coast from 2001 to 2100 under the RCP 2.6 scenario.

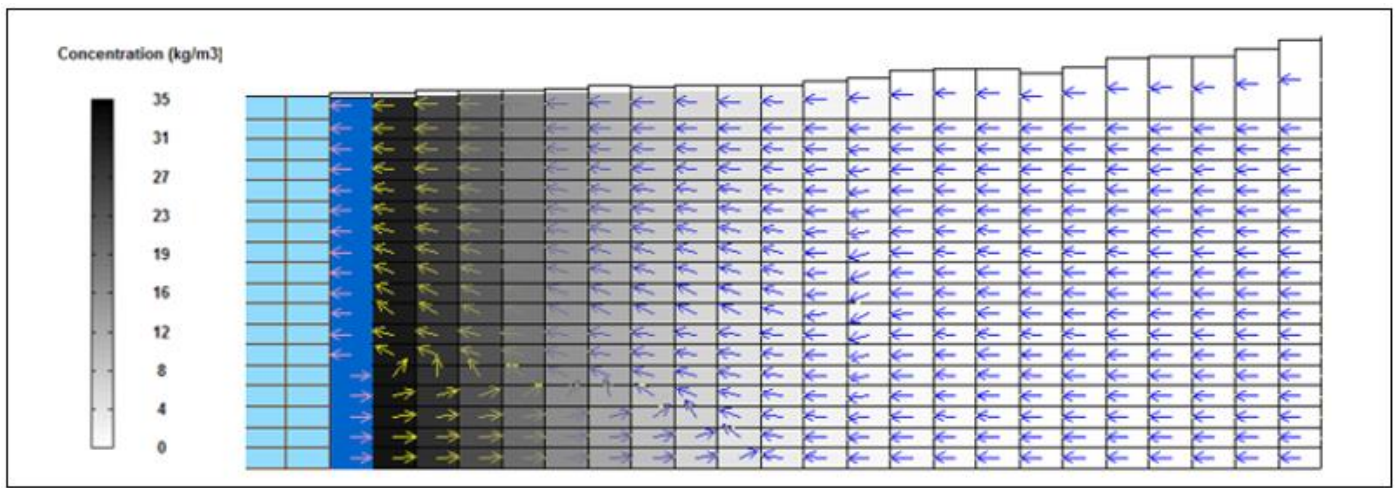

Figure 17. Location of the seawater intrusion in the area of Ambabbo locality in 2100 under scenario RCP 2.6. NS vertical section. Concentration in $\mathrm{kg} / \mathrm{m}^{3}$.

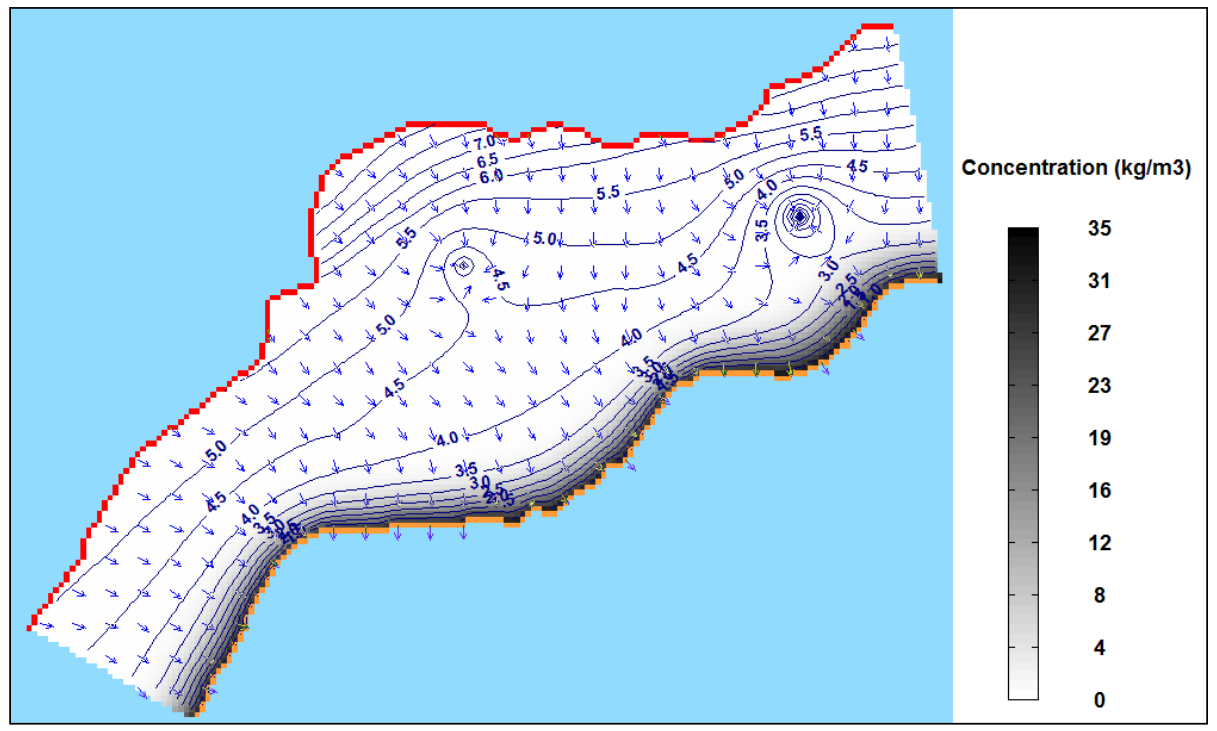

Figure 18. Groundwater piezometry in 2100 and concentration at the surface in layer 1 under the RCP 2.6 scenario.

The results of the three scenarios lead to the same conclusions. Recall that the average annual rainfall simulated by these three scenarios is quite comparable. The difference between the three 
scenarios is due to the appearance of exceptional rainfall events whose number and years of occurrence are not the same for the three scenarios. These results show that climate change will have negative impacts on this aquifer and that seawater intrusion poses a real threat to the sustainability of these resources. In this work, we mainly considered the impact of climate change on precipitation and thus on the recharge of the aquifer system. It should be noted that at this stage some uncertainties are involved in the calculation of global warming within climate scenarios. The rise in sea level due to climate change should also be taken into account.

In some parts of the world, predictions of sea level rise can be quite large. In the United States, on the California coast, the sea-level rise forecasts, depending on the scenarios, can reach $1.5 \mathrm{~m} /$ century compared to 1990 [53,54]. On the Djiboutian coast, simulations of climate scenarios predict a sea level rise of $8 \mathrm{~cm}$ to $39 \mathrm{~cm} \mathrm{[55],} \mathrm{much} \mathrm{less} \mathrm{important} \mathrm{than} \mathrm{in} \mathrm{other} \mathrm{regions} \mathrm{of} \mathrm{the} \mathrm{globe.} \mathrm{The} \mathrm{uncertainty}$ associated with these forecasts also remains important. In addition, the impact of sea level rise occurs away from the coastline, where the water table is more affected by pumping and recharge rates than the increase or decrease in the sea level [56]. Given these considerations and in order not to exaggerate the uncertainty associated with modeling results, sea level rise has not been considered in the modeling work.

\section{Summary and Conclusions}

The objective of this work was to analyze the response of the Tadjourah coastal aquifer (Republic of Djibouti) to climate change over the period 2001-2100 and to predict its potential to meet water demands. This aquifer is used for drinking water supply in the city of Tadjourah. Given the future development of the urban population and the economic activities of this region, water needs will increase drastically. To study the impact of climate change on the functioning of this coastal aquifer, three scenarios of the IPCC have been implemented: RCP 2.6, RCP 4.5 and RCP 8.5. The scenario RCP 2.6 simulates, during 2001-2100, a rainfall series with a downward trend, comparable to what one observes currently. Scenarios RCP 4.5 and 8.5 simulate rainfall with a slight upward trend. The three scenarios simulate exceptional rainfall events. These exceptional events are more numerous in scenarios RCP 4.5 and RCP 8.5, causing this paradoxical upward trend. The precipitations simulated by these scenarios were used to estimate the recharge of the aquifer and simulate its functioning over the period 2001-2100, using a 3D numerical model integrating the freshwater-saltwater interface. The aquifer is exploited using two wells, Pk6 and Pk9. At equilibrium, the model reproduces well the observed piezometry of the aquifer in steady state and without exploitation. Running the model under the three scenarios resulted in the same conclusions. The simulations showed that seawater intrusion does not stabilize but continues to advance. There is no stabilization of the concentrations in the aquifer. In 2100, the exploitation of well Pk9 is still spared by the seawater intrusion. On the other hand, Pk6 well is affected by salt contamination. All these results show that the aquifer is in a critical situation. No increase in the exploitation of the groundwater can be envisaged. Maintaining current exploitation by both Pk6 and Pk9 wells requires a thorough monitoring of the seawater intrusion advance. For this purpose, the situation of Pk6 well is more serious than that of Pk9 well.

The results of this study demonstrate that understanding the impacts of climate changes on groundwater resources, and specifically in coastal aquifers, is crucial for water resources management. Although these results are not entirely certain, given the uncertainties associated with climate scenarios, such an approach, associating climate scenarios and numerical modeling of aquifers, proves useful for understanding the future reactions of hydrogeological systems and to envisage measurements of adaptation and protection of the water resources. For the coastal aquifer of Tadjourah, the study shows that the risk of contamination of this system by seawater intrusion is high. It is expected that end-users will positively consider this study to preserve the long-term exploitation of this aquifer as part of the sustainable management of its water resources.

Author Contributions: Conceptualization, M.R., M.J. and A.H.-G.; methodology, M.R., M.J. and A.H.-G.; software, M.R.; validation, M.R.; formal analysis, M.R.; investigation, M.R., M.J. and A.H.-G.; resources, M.R., M.J. and 
A.H.-G.; data curation, M.R., M.J., A.H.-G.; Writing-Review and editing, M.R.; visualization, M.R.; supervision, M.R.; project administration, M.R., M.J. and A.H.-G.; funding acquisition, M.R., M.J. and A.H.-G.

Funding: This research was funded by the Ministère de l'Habitat, de l'Urbanisme et de l'Environnement of the Republic of Djibouti.

Acknowledgments: The authors would like to thank the IGAD-CPAC (Inter-Governmental Authority on Development-Climate Prediction and Application Center) in Nairobi, for their collaboration in climate scenarios simulations. The author also acknowledges the comments by 3 anonymous reviewers which helped to improve the manuscript.

Conflicts of Interest: The authors declare no conflict of interest. The funders had no role in the design of the study; in the collection, analyses, or interpretation of data; in the writing of the manuscript, or in the decision to publish the results.

\section{Appendix A Calibration of the Model}

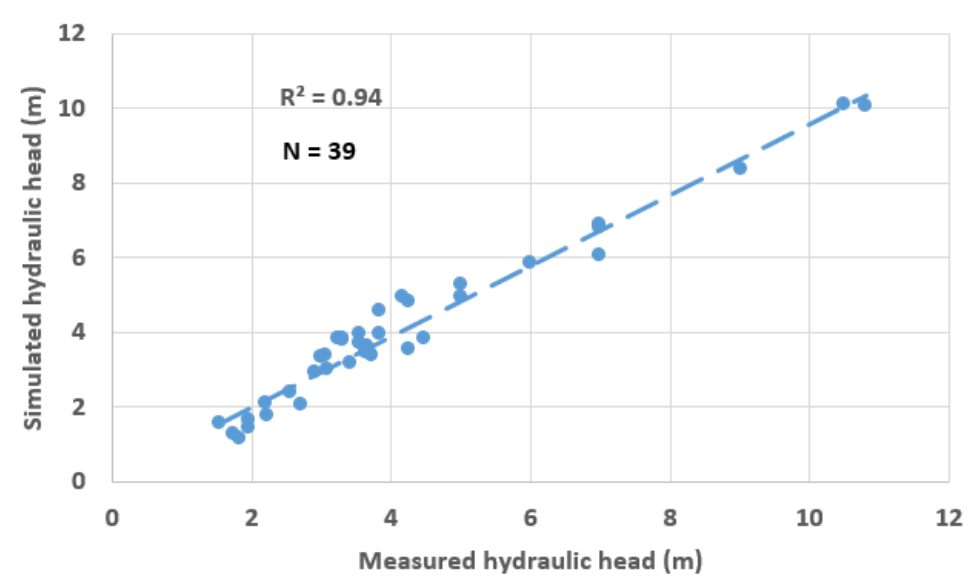

Figure A1. Simulated hydraulic head vs. Measured hydraulic head.

Table A1. Model calibration statistics.

\begin{tabular}{cccc}
\hline Determination Coefficient & Mean Error (m) & Mean Absolute Error (m) & Root Mean Square Error (m) \\
\hline 0.94 & 0.16 & 0.45 & 0.54 \\
\hline
\end{tabular}

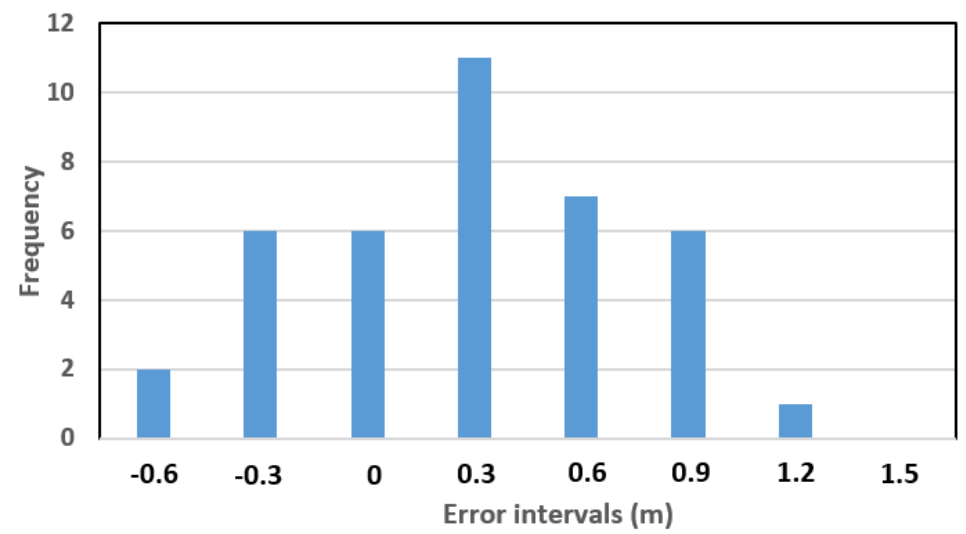

Figure A2. Distribution of the errors. 


\section{Appendix B Simulation of Climate Change Impact up to 2100 under RCP Scenario 4.5}
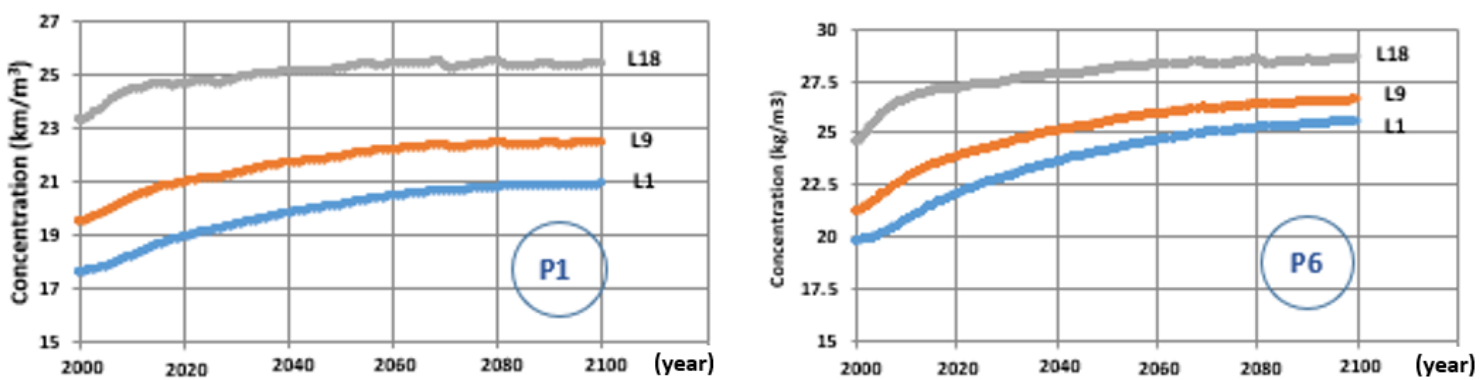

Figure A3. Concentrations variation at monitoring piezometers P1 and P6 (100 m from the coast) under RCP scenario 4.5. L1: layer 1; L9: layer 9; L18: layer 18.

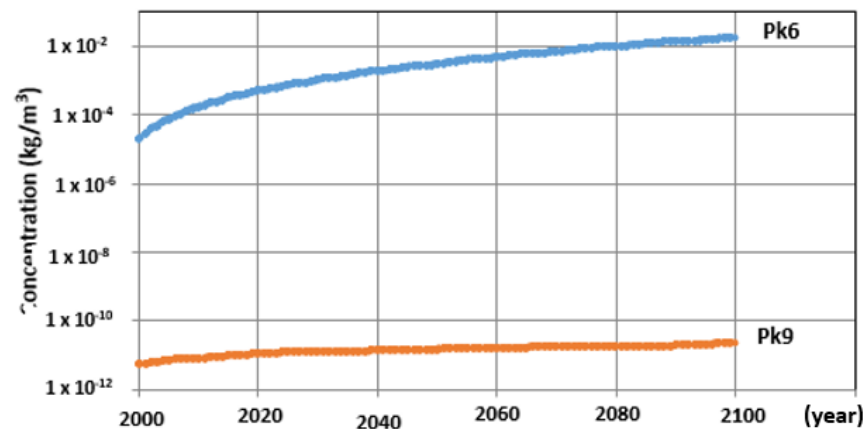

Figure A4. Concentrations variation at wells Pk6 and Pk9 under RCP scenario 4.5.

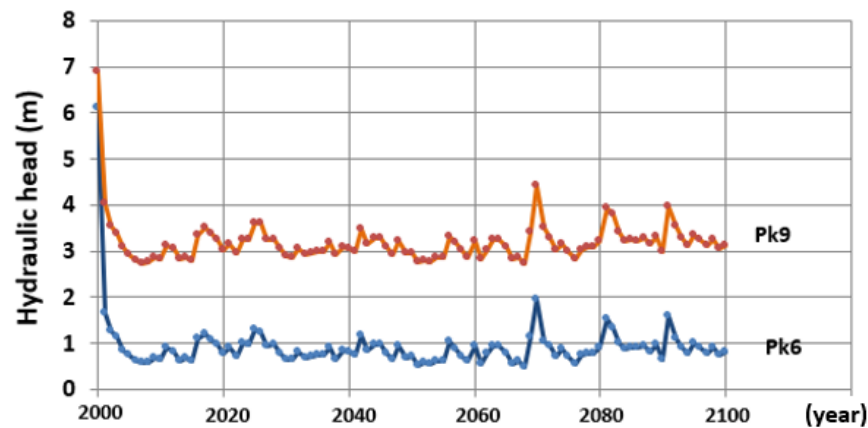

Figure A5. Piezometric variations at wells Pk9 and Pk6 from 2001 to 2100 under scenario RCP 4.5.

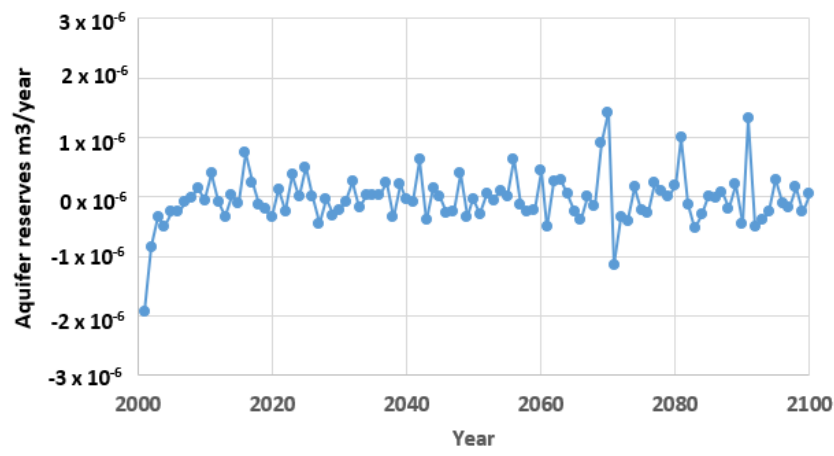

Figure A6. Changes in aquifer reserves from 2001 to 2100 under scenario RCP 4.5. 


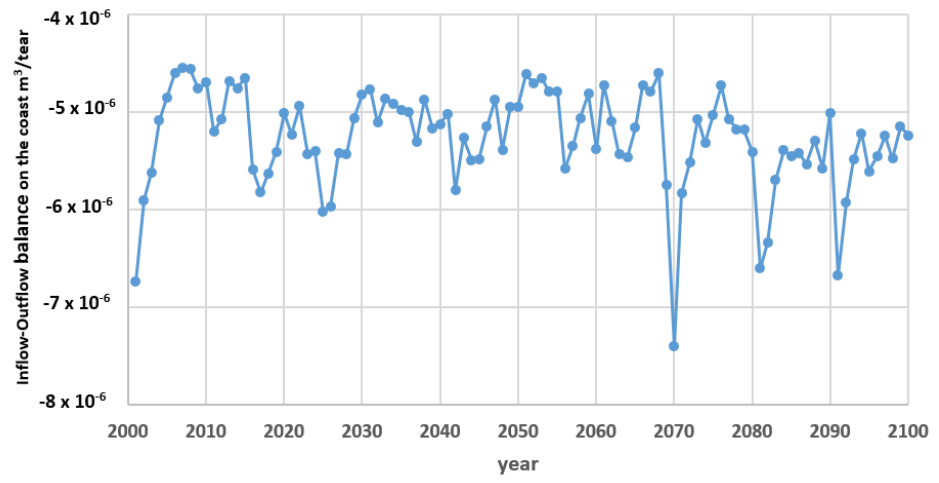

Figure A7. Inputs/Outputs balance on the coast from 2001 to 2100 under scenario RCP 4.5.
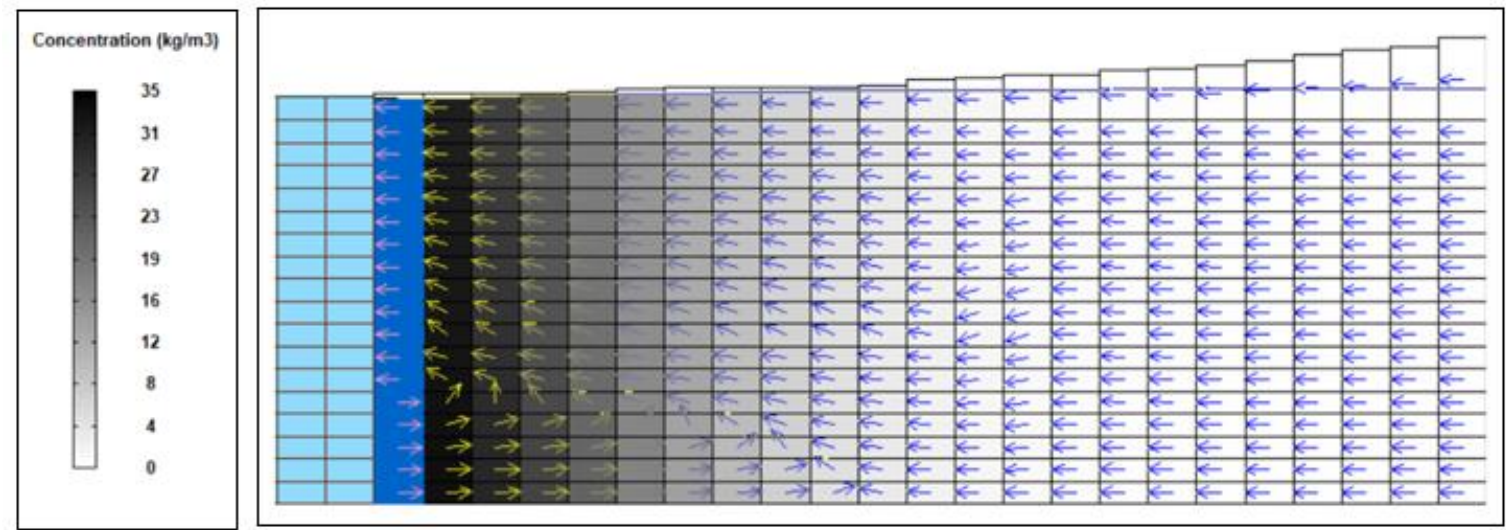

Figure A8. Location of the seawater intrusion in the area of Ambabbo locality in 2100 under scenario RCP 4.5. NS vertical section. Concentration in $\mathrm{kg} / \mathrm{m}^{3}$.

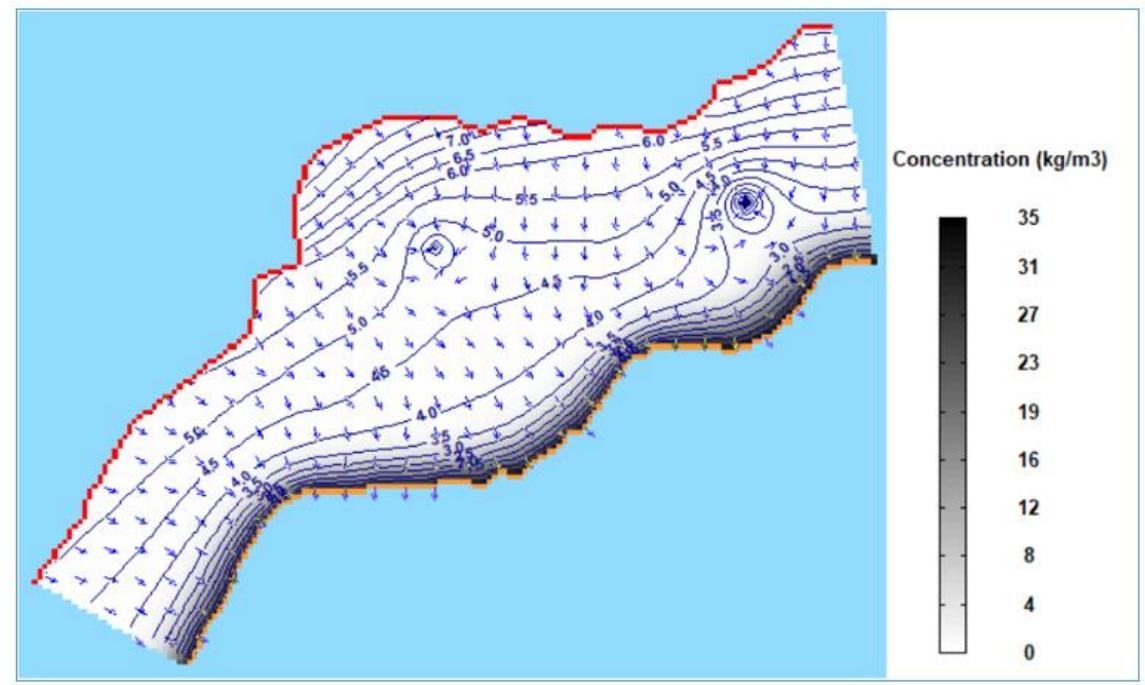

Figure A9. Groundwater piezometry in 2100 and concentration at the surface in layer 1 under the RCP 4.5 scenario. 


\section{Appendix C Simulation of Climate Change Impact up to 2100 under RCP Scenario 8.5}
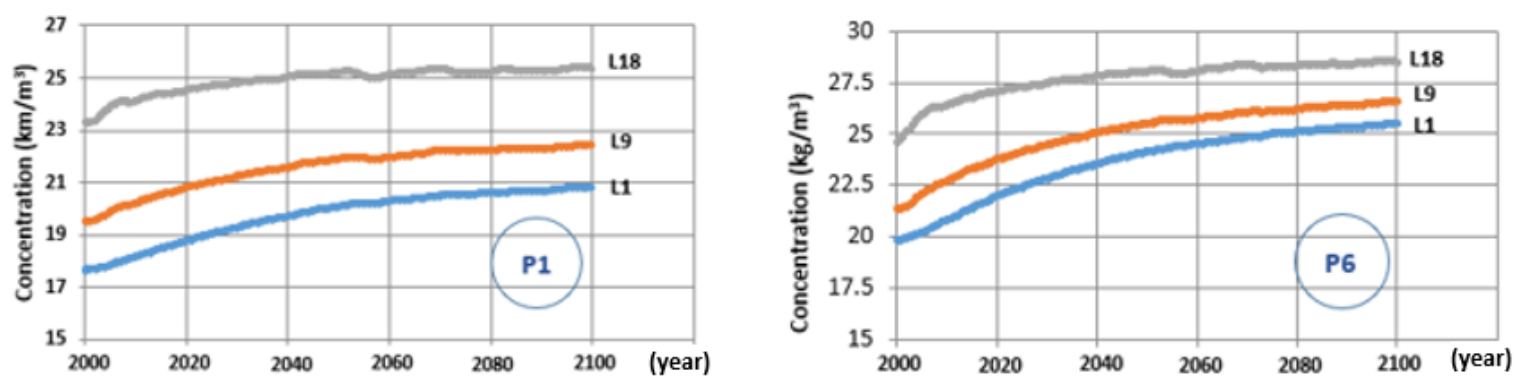

Figure A10. Concentrations variation at monitoring piezometers P1 and P6 (100 m from the coast) under RCP scenario 8.5. L1: layer 1; L9: layer 9; L18: layer 18.

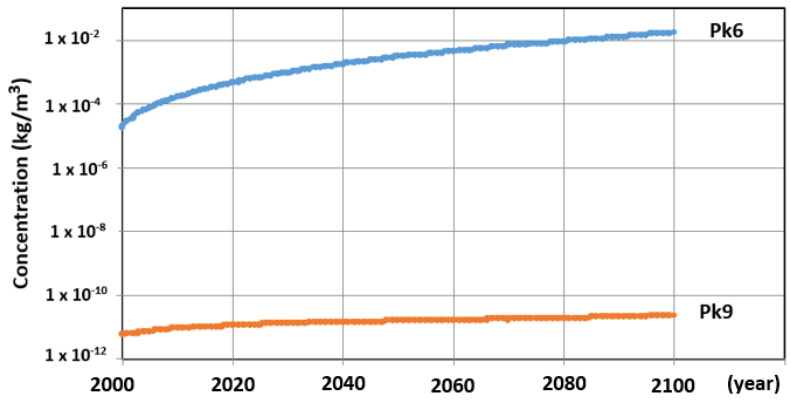

Figure A11. Concentrations variation at wells Pk6 and Pk9 under RCP scenario 8.5.

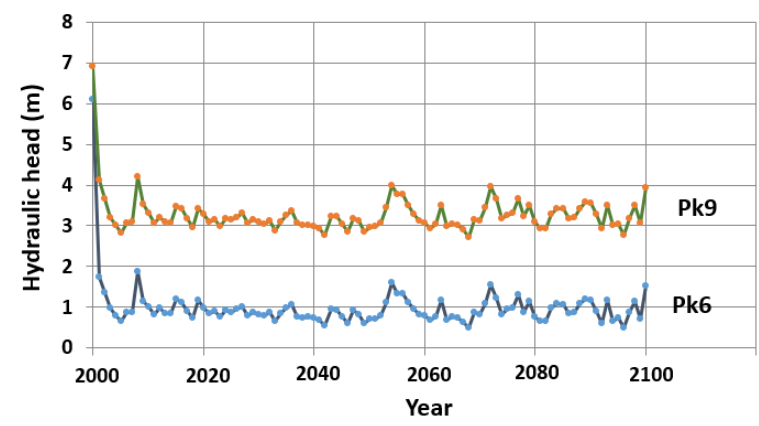

Figure A12. Piezometric variations at wells Pk9 and Pk6 from 2001 to 2100 under scenario RCP 8.5.

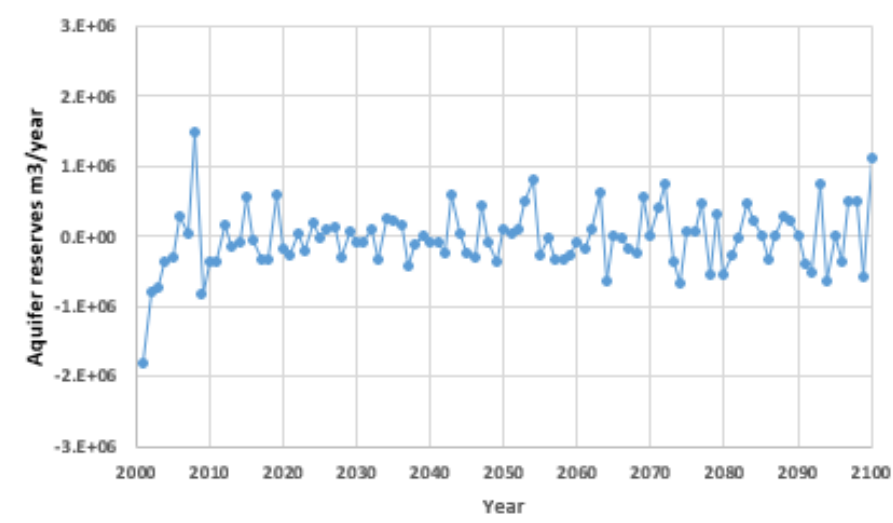

Figure A13. Changes in aquifer reserves from 2001 to 2100 under scenario RCP 8.5. 


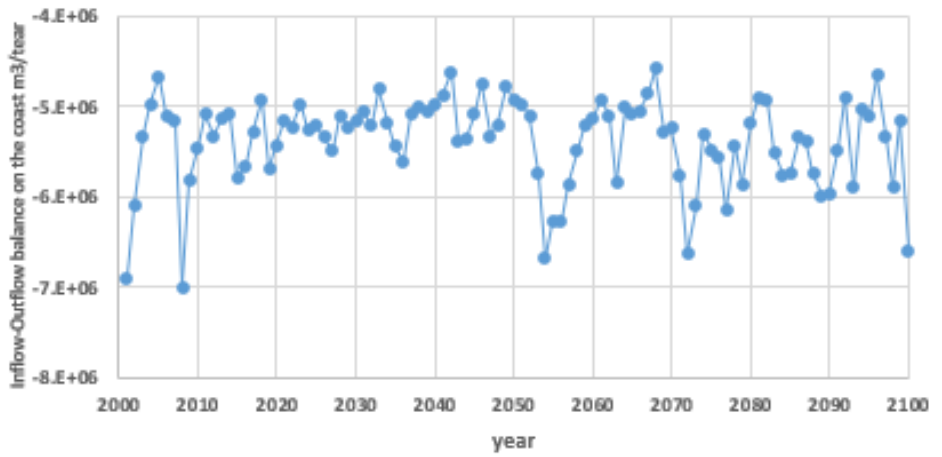

Figure A14. Inputs/Outputs balance on the coast from 2001 to 2100 under scenario RCP 8.5.

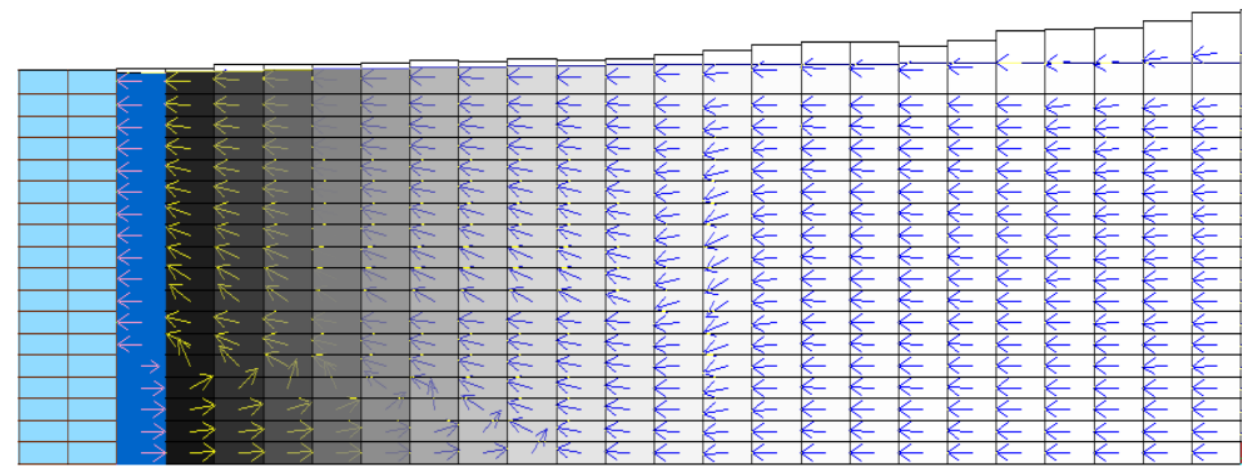

Figure A15. Location of the seawater intrusion in the area of Ambabbo locality in 2100 under scenario RCP 8.5. NS vertical section. Concentration in $\mathrm{kg} / \mathrm{m}^{3}$ (Concentration scale in Figure 7).

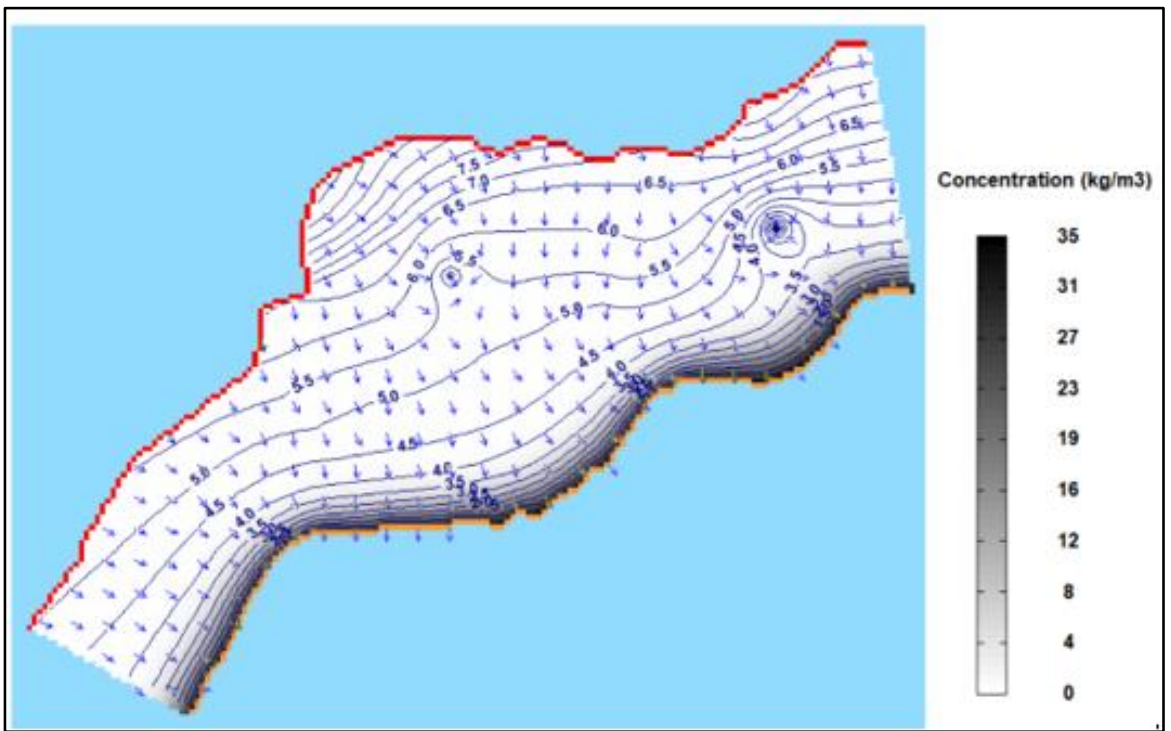

Figure A16. Groundwater piezometry in 2100 and concentration at the surface in layer 1 under the RCP 8.5 scenario.

\section{References}

1. Mukherjee, A.; Saha, D.; Harvey, C.F.; Taylor, R.G.; Ahmed, K.M.; Bhanja, S.N. Groundwater systems of the Indian sub-continent. J. Hydrol. Reg. Stud. 2015, 4, 1-14. [CrossRef]

2. Watto, M.A.; Mugera, A.W. Econometric estimation of groundwater irrigation efficiency of cotton cultivation farms in Pakistan. J. Hydrol. Reg. Stud. 2015, 4, 193-211. [CrossRef] 
3. Jalludin, M. Groundwater ressources and challenges of future water supply of the Republic of Djibouti under arid climate (Horn of Africa). In Aquifer Systems Management; CRC Press: Dijon, France, 2006.

4. Steyl, G.; Dennis, I. Review of coastal-area aquifers in Africa. Hydrogeol. J. 2010, 18, 217-225. [CrossRef]

5. Ummenhofer, C.C.; Sen Gupta, A.; England, M.H.; Reason, C.J.C. Contributions of Indian Ocean sea surface temperatures to enhanced East Africanrainfall. J. Clim. 2009, 22, 993-1013. [CrossRef]

6. MacDonald, A.M.; Bonsor, H.C.; Dochartaigh, B.É.Ó.; Taylor, R.G. Quantitative maps of groundwater resources in Africa. Environ. Res. Lett. 2012, 7, 024009. [CrossRef]

7. Walraevens, K.; Mjemah, I.C.; Mtoni, Y.; Van Camp, M. Sources of salinity and urban pollution in the Quaternary sand aquifers of Dar es Salaam, Tanzania. J. Afr. Earth Sci. 2015, 102, 149-165. [CrossRef]

8. Fetter, C.W. Applied Hydrogeology, 3rd ed.; Prentice-Hall: Englewood Cliffs, NJ, USA, 1994; p. 690.

9. Bear, J.; Verruijt, A. Modeling Groundwater Flow and Pollution; D. Reidel Publishing Company: Dordrecht, The Netherlands, 1987; p. 414.

10. Felisa, G.; Ciriello, V.; Di Federico, V. Saltwater Intrusion in Coastal Aquifers: A Primary Case Study along the Adriatic Coast Investigated within a Probabilistic Framework. Water 2013, 5, 1830-1847. [CrossRef]

11. Cassardo, C.; Jones, J.A.J. Managing water in a changing world. Water 2011, 3, 618-628. [CrossRef]

12. Gain, A.K.; Giupponi, C.; Renaud, F.G. Climate change adaptation and vulnerability assessment of water resources systems in developing countries: A generalized framework and a feasibility study in Bangladesh. Water 2012, 4, 345-366. [CrossRef]

13. Capaccioni, B.; Didero, M.; Paletta, C.; Didero, L. Saline intrusion and refreshening in a multilayer coastal aquifer in the Catania Plain (Sicily, southern Italy): Dynamics of degradation processes according to the hydrochemical characteristics of groundwater. J. Hydrol. 2005, 307, 1-16. [CrossRef]

14. De Luca, A.; Preziosi, E.; Giuliano, G.; Mastroianni, D.; Falconi, F. First evaluation of the saltwater intrusion in the Tiber delta area (Rome, central Italy). In Proceedings of the 18th Salt Water Intrusion Meeting, Cartagena, Spain, 31 May-3 June 2004; p. 34.

15. Hinkel, J.; Brown, S.; Exner, L.; Nicholls, R.J.; Vafeidis, A.T.; Kebede, A.S. Sea-level rise impacts on Africa and the effects of mitigation andadaptation: An application of DIVA. Reg. Environ. Chang. 2012, 12, 207-224. [CrossRef]

16. Du, X.; Lu, X.; Hou, J.; Ye, X. Improving the Reliability of Numerical Groundwater Modeling in a Data-Sparse Region. Water 2018, 10, 289. [CrossRef]

17. United Nations. World Population Prospects: The 2010 Revision; UN Department of Economic and Social Affairs, Population Division: New York, NY, USA, 2011; Available online: https://www.un.org (accessed on 1 July 2019).

18. MHUE (Ministère de l'Habitat, de l'Urbanisme et de l'Environnement). Ville de Tadjourah. Esquisses du Schema de Développement et D'orientation. P.71. 2013. Available online: https://www.djiboutinfo.org (accessed on 1 July 2019).

19. CERD. Geological Map of Djibouti. Sheet of Tadjourah at 1/100000; CERD: Djibouti, Republic of Djibouti, 1984.

20. AQUATER. Projet Pour L'évaluation des Ressources Géothermiques. AQUATER-ISERST; ISERST: Djibouti, Republic of Djibouti, 1981; Volume 2, p. 137, Unpublished Report.

21. BGR (Bundesanstalt für Geowissenschaften und Rohstoffe, Hanover, Germany). Inventaire et Mise en Valeur des Ressources en eau de la République de Djibouti. [Inventory and Evaluation of the Water Resources of the Republic of Djibouti); Ministère de l'Agriculture et de l'Elevage: Djibouti, Republic of Djibouti, 1982; Volume 4, Unpublished.

22. IFAGRARIA. Projet d'Aménagement d'un Périmètre Hydro-Agricole à Ambabbo-District de Tadjourah; Ministère de l'Agriculture et de l'Elevage: Djibouti, Republic of Djibouti, 1986; Unpublished.

23. Abdourahman, H.G. L'aquifère côtier de Tadjourah: Synthèse des Connaissances et Modélisation en vue de la Gestion des Ressources en eau (République de Djibouti). Master's Thesis, University of Poitiers, Poitiers, France, 2004; p. 52. Unpublished. (In French).

24. Jalludin, M. Propriétés Géométriques et Hydrodynamiques des Aquifères en Milieux Volcaniques Fissurés sous Climat Aride. République de Djibouti. Ph.D. Thesis, University of Poitiers, Poitiers, France, 1993. (In French).

25. Jalludin, M.; Razack, M. Analysis of pumping tests in fractured Dalha and stratiform basalts with regards to tectonics, hydrothermalisms and weathering. Republic of Djibouti. J. Hydrol. 1994, 155, 237-250. [CrossRef] 
26. Jalludin, M.; Razack, M. Assessment of hydraulic properties of sedimentary and volcanic aquifer systems under arid conditions in the Republic of Djibouti (Horn of Africa). Hydrogeol. J. 2004, 12, 159-170. [CrossRef]

27. Gamal-Eldin, H.A. Etude de l'aquifère Basaltique de la Zone de Captage de la Ville de Djibouti. République de Djibouti. Ph.D. Thesis, University Albert-Ludwig, Fribourg, Germany, 1988. Unpublished.

28. Medjerab, A. Les situations pluviométriques extrêmes dans le nord-ouest de l'Algérie. In Climat, Tourisme, Environnement; Actes du XXème Colloque de 1'Association Internationale de Climatologie: Carthage, Tunisie, 2007; pp. 381-386.

29. Gee, G.W.; Hillel, D. Groundwater recharge in arid regions: Review and critique of estimation its methods. Hydrol. Process. 1988, 2, 255-266. [CrossRef]

30. Nimmo, J.R.; Horowitz, C.; Mitchell, L. Discrete-Storm Water-Table Fluctuation Method to Estimate Episodic Recharge. Groundwater 2015, 53, 282-292. [CrossRef]

31. Zhang, J.; Felzer, B.S.; Troy, T.J. Extreme precipitation drives groundwater recharge: The Northern High Plains Aquifer, central United States, 1950-2000. Hydrol. Process. 2016, 30, 2533-2545. [CrossRef]

32. Thomas, B.F.; Ali Behrangi, A.; Famiglietti, J.S. Precipitation Intensity Effects on Groundwater Recharge in the Southwestern United States. Water 2016, 8, 90. [CrossRef]

33. Giorgi, F.; Francisco, R. Evaluating uncertainties in the prediction of regional climate change. Geophys. Lett. 2000, 27, 1295-1298. [CrossRef]

34. Aggarwal, P.K.; Mall, R.K. Climate Change and Rice Yields in Diverse Agro-Environments of India. II. Effect of Uncertainties in Scenarios and Crop Models on Impact Assessment. Clim. Chang. 2002, 52, 331-343. [CrossRef]

35. Velázquez, J.A.; Schmid, J.; Ricard, S.; Muerth, M.; St-Denis, B.G.; Minville, M.; Chaumont, D.; Caya, D.; Ludwig, R.; Turcotte, R. An ensemble approach to assess hydrological models' contribution to uncertainties in the analysis of climate change impact on water resources. Hydrol. Earth Sci. 2013, 17, 565-578. [CrossRef]

36. Kum, D.; Lim, K.J.; Jang, C.H.; Ryu, J.; Yang, J.E.; Kim, S.J.; Kong, D.S.; Jung, Y. Projecting Future Climate Change Scenarios Using Three Bias-Correction Methods. Adv. Meteorol. 2014, 2014, 1-12. [CrossRef]

37. IPCC. Climate Change 2014: Synthesis Report. Contribution of Working Groups I, II and III to the Fifth Assessment Report of the Intergovernmental Panel on Climate Change; Core Writing Team, Pachauri, R.K., Meyer, L.A., Eds.; IPCC: Geneva, Switzerland, 2014; p. 151. Available online: https://archive.ipcc.ch/pdf/assessment-report/ar5 (accessed on 1 July 2019).

38. Lee, J.M.; Jung, Y.; Park, Y.; Kang, H.; Lim, K.J.; Kim, H. Assessment of Future Climate Change Impact on Groundwater recharge, Baseflow and Sediment in Steep SlopingWatershed. J. Wetl. 2014, 16, 173-185. [CrossRef]

39. Fiseha, B.M.; Setegn, S.G.; Melesse, A.M.; Volpi, E.; Fiori, A. Impact of Climate Change on the Hydrology of Upper Tiber River Basin Using Bias Corrected Regional Climate Model. Water Resour. Manag. 2014, 28, 1327-1343. [CrossRef]

40. Verma, S.; Bhattarai, R.; Bosch, N.S.; Cooke, R.C.; Kalita, P.K.; Markus, M. Climate Change Impacts on Flow, Sediment and Nutrient Export in a Great Lakes Watershed Using SWAT. CLEAN Soil Air Water 2015, 43, 1464-1474. [CrossRef]

41. Mastrocicco, M.; Busico, G.; Colombani, N.; Vigliotti, M.; Ruberti, D. Modelling Actual and Future Seawater Intrusion in the Variconi CoastalWetland (Italy) Due to Climate and Landscape Changes. Water 2019, 11, 1502. [CrossRef]

42. Langevin, C.D.; Shoemaker, B.; Guo, W. Documentation of the SEAWAT-2000 Version with the Variable-Density Flow Process (VDF) and the Integrated MT3DMS Transport Process (IMT); Open File Report 03-426; United States Geological Survey: Tallahassee, FL, USA, 2003; p. 44.

43. McDonald, M.G.; Harbaugh, A.W. A Modular Three-Dimensional Finite-Difference Ground-Water Flow Model; Survey Techniques of Water Resources Investigations; U.S. Geological Survey: Reston, VA, USA, 1988; p. 586.

44. Zheng, C. MT3D-A Modular Three-Dimensional Transport Model for Simulation of Advection, Dispersion and Chemical Reactions of Contaminants in Groundwater Systems; S.S. Papadopulos \& Associates, Inc.: Bethesda, MD, USA, 1996.

45. Rao, S.V.N.; Sreenivasulu, V.; Bhallamudi, S.M.; Thandaveswara, B.S.; Sudheer, K.P. Planning groundwater development in coastal aquifers. Hydrol. Sci. J. 2004, 49, 155-170. [CrossRef]

46. Moustadraf, J.; Razack, M.; Sinan, M. Evaluation of the impacts of climate changes on the coastal Chaouia aquifer, Morocco, using numerical modeling. Hydrogeol. J. 2008, 7, 1411-1426. [CrossRef]

47. Schneider, J.C.; Kruse, S.E. A comparison of controls on freshwater lens morphology of small carbonate and siliciclastic islands: Examples from barrier islands in Florida, USA. J. Hydrol. 2003, 284, 253-269. [CrossRef] 
48. Bonte1, M.; Biesheuvel, A. The application of the SEAWAT variable density code for the Lake Wieringen project, the Netherlands. In Proceedings of the 1st SWIM-SWICA Joint Saltwater Intrusion Conference, Cagliari-Chia Laguna, Italy, 24-29 September 2006; pp. 45-52.

49. Qahman, K.; Larabi, A. Evaluation and numerical modeling of seawater intrusion in the Gaza aquifer (Palestine). Hydrogeol. J. 2006, 14, 713-728. [CrossRef]

50. Al-Maktoumi, A.; Lockington, D.A.; Volker, R.E. SEAWAT 2000: Modelling unstable flow and sensitivity to discretization levels and numerical schemes. Hydrogeol. J. 2007, 15, 1119-1129. [CrossRef]

51. Bauer, P.; Held, R.J.; Zimmermann, S.; Linn, F.; Kinzelbach, W. Coupled flow and salinity transport modelling in semi-arid environments: The Shashe River Valley, Botswana. J. Hydrol. 2006, 316, 163-183. [CrossRef]

52. Anderson, M.P.; Woessner, W.M. Applied Groundwater Modelin; Academic Press: San Diego, CA, USA, $1992 ;$ p. 381.

53. Hoovera, D.J.; Odigiea, K.O.; Swarzenskia, P.W.; Barnarda, P. Sea-level rise and coastal groundwater inundation and shoaling at select sites in California, USA. J. Hydrol. Reg. Stud. 2017, 11, 234-249. [CrossRef]

54. Cayan, D.R.; Bromirski, P.D.; Hayhoe, K.; Tyree, M.; Dettinger Flick, R.E. Climate change projections of sea level extremes along the California coast. Clim. Chang. 2008, 87, S57-S73. [CrossRef]

55. MHUE. (Ministère de l'Habitat, de l'Urbanisme et de l'Environnement). Seconde Communication Nationale de la République de Djibouti à la Convention Cadre des Nations Unies Sur les Changements Climatiques (Second National Communication of the Republic of Djibouti to the United Nations Convention on Climate Change). 2013. Available online: http://www.environnement.dj/ (accessed on 1 May 2019). (In French).

56. Sherif, M.; Singh, V.P. Effect of climate change on sea water intrusion in coastal aquifers. Hydrol. Process. 1999, 13, 1277-1287. [CrossRef]

(C) 2019 by the authors. Licensee MDPI, Basel, Switzerland. This article is an open access article distributed under the terms and conditions of the Creative Commons Attribution (CC BY) license (http://creativecommons.org/licenses/by/4.0/). 